\title{
Norforce: Major General Edward Northey and the Nyasaland and North- Eastern Rhodesia Frontier Force, January 1916 to June 1918
}

\author{
Ross Anderson •
}

\begin{abstract}
The campaign in East and Central Africa during the First World War has received relatively little attention despite the remarkable exploits of Major General Edward Northey and Norforce. In field command for two and a half years, he successfully led a multi-ethnic and polyglot force across some of the most difficult terrain of the war. Exerting strong leadership and overseeing detailed logistical planning, Northey was able to maintain an effective force that was consistently able to march and fight the German Schutztruppe under von Lettow-Vorbeck. In contrast to the main body of the British East African Force, Norforce maintained its combat effectiveness despite high levels of sickness and highly trying climatic conditions. Overall, Northey must be considered the outstanding British general of the East African Campaign while Norforce deserves full credit for its singular achievements.
\end{abstract}

Keywords: East \& Central Africa, Edward Northey, Norforce, First World War

\section{Introduction}

Despite increasing scholarly interest, the East African campaign of 1914-1918 has remained one of the lesser-studied theatres of the First World War. ${ }^{1}$ If strategically it was a 'peripheral' theatre to the European powers, it had an enormous and lasting effect on the region and its inhabitants. The environment, physical and human in Africa played a decisive role in determining military success or failure: innovation was essential to overcome the extremely limited infrastructure, a largely subsistence economy and a subject population of great diversity that had little interest in European quarrels. In a theatre with extremes of distance, terrain and climate, military operations had to be carried out very differently from those in Europe or the Near East. ${ }^{2}$

On the British side, the remarkable achievements of Major General (Maj. Gen.) Edward Northey and the Nyasaland and North-Eastern Rhodesia Frontier Force have remained in the shadow of the East African Force under General (Gen.) Jan Smuts. This is undeserved as Norforce, as it was usually known after its less cumbersome telegraphic address, achieved considerable success through tremendous feats of endurance under some of the most demanding conditions in the world. While Northey was a regular British officer from the English gentry, his heterogeneous and polyglot troops were drawn from across Great Britain, South Africa, Uganda, both Northern Rhodesia (Zambia) and Southern Rhodesia (Zimbabwe) and Nyasaland (Malawi). Despite his command not being much more than a reinforced infantry brigade until 1918, Norforce advanced thousands of kilometres during its existence, often with detached columns operating up to several hundred kilometres apart with lines of communication extending over 1200 kilometres to the rear. Aided only by a small staff, Gen. Northey was a successful commander of a highly capable fighting force that played a crucial role in the conquest of German East

Ross Anderson served for many years an infantry officer first in the Canadian and subsequently the British Armies. He now specialises in the military history of the First World War in Africa and the Middle East with a forthcoming book on the King's African Rifles. 
Africa as well as the subsequent pursuit of the German Schutztruppe through Mozambique and Northern Rhodesia. ${ }^{3}$ Furthermore, Norforce's organisational success was in sharp contrast to the administrative failures that bedevilled British columns operating from British East Africa throughout much of 1916. This article attempts to redress the imbalance through a description and assessment of Edward Northey's tenure in command of Norforce.

\section{The strategic situation}

At the outbreak of war in August 1914, the British East African territories were of marginal strategic importance to the empires that were about to engage in a titanic struggle in Europe. ${ }^{4}$ These virtually undeveloped regions were controlled by the Colonial Office, which governed through a small number of European officials who collected taxes from the substantial numbers of indigenous Africans. The economy was overwhelmingly agricultural and largely subsistence-based with manufactured goods having to be imported by sea. European settlement was sparse and isolated with poor communication networks, making journeys take weeks rather than days. Colonial control was exerted through locally raised military units and paramilitary police commanded by whites. There were a total of three battalions of the King's African Rifles (KAR) in East Africa, totalling nearly 2400 soldiers of which only the Depot and three companies of $1^{\text {st }}$ Battalion KAR $\left(1^{\text {st }}\right.$ KAR) were based in Nyasaland with the remainder in Uganda and British East Africa. ${ }^{5}$ Northern Rhodesia was little better off with some 450 members of the paramilitary Northern Rhodesian Police (NRP) to cover its vast expanse and extensive frontier with German East Africa. Altogether, there were fewer than 1000 military and police available to secure a border in excess of 480 kilometres.

Across the frontier, the forces in German East Africa were comparable to the KAR with 2600 troops organised in 14 companies of the Schutztruppe, although there were barely 150 along the southern border with a platoon at Bismarckburg (Kasanga) and a company near Neu Langenburg (Tukuyu). They, too, suffered from poor physical communications and were reliant on a heliograph system to link Neu Langenburg to Iringa and then Kilossa, the site of the nearest telegraph station. ${ }^{6}$ However, if they were not in the position to launch a full-scale invasion, the Schutztruppe were vigorously led and quite capable of threatening vulnerable frontier posts. For both sides, their units were very lightly equipped, as they had to operate in the African bush with their supplies and equipment carried by indigenous Africans, known as 'carriers' or 'porters'. There was no artillery or advanced military equipment as these troops were intended to enforce colonial rule and not to face a modern enemy in general war. Overall, the region was a military backwater that was entirely unprepared for major conflict.

With the outbreak of war, British strategy concentrated on seizing the German seaports along the Indian Ocean coast in order to neutralise the latter's naval raiders. Significant reinforcements in the form of two brigades of Indian infantry were despatched to British East Africa, but poor preparation and an underestimation of the Schutztruppe led to the debacle at Tanga on 30 October-2 November 1914. Faced by a strong enemy, London ordered the forces in East Africa over to the defensive on which they remained for the rest of the year and much of $1915 .^{7}$

For their part, the Germans had reinforced the southern border, gaining command of Lake Tanganyika, thereby threatening Abercorn (Mbala) and the north-eastern portion of the border whereas the British had achieved supremacy on Lake Nyasa (Malawi). An attack on Karonga, in northern Nyasaland on 9 September 1914 was countered decisively by $1^{\text {st }}$ KAR, but underlined the paucity of forces along the border. ${ }^{8}$ The hopes of the Colonial Office that the landings at Tanga would relieve the pressure in the south were dashed by the failure there and it now had to turn to its own resources for military manpower. The British authorities lacked vision: they were reluctant to expand the KAR, for 
financial reasons, while also hesitating to train large bodies of African forces for fear of potentially undermining colonial rule. Even the overwhelming military logic of having a single officer to command all the British forces in the region was rejected owing to departmental rivalry. ${ }^{9}$

The year 1915 opened in an uneasy stalemate. In January, Nyasaland was shaken by an African uprising between Zomba and Blantyre led by John Chilembwe. The revolt was quickly suppressed by $1^{\text {st }}$ KAR and settlers, but it underlined the fragility of British rule and the scarcity of military forces. Both sides struggled to maintain detached fighting columns scattered over vast distances and backed by poor lines of communication. The Germans had reinforced to the equivalent of about five companies totalling about 500 soldiers based in the garrisons of Bismarckburg and Neu Langenburg, themselves 320 kilometres apart, while the British could barely muster 500 in Nyasaland and a similar number in Northern Rhodesia. Interestingly enough, it was the Belgians who had the greatest power with three battalions numbering more than 1500 men based in the Katanga Province of their Congo territory. The Portuguese remained officially non-belligerent and held a number of isolated detachments throughout its Mozambique colony, which were of virtually negligible fighting power.

At the same time, a similar threat emerged in the east when troops from Bismarckburg attacked Abercorn in Northern Rhodesia. With British reinforcements still some distance away, the local magistrate sought and obtained support from the Belgian forces in the neighbouring Congo. By the end of the month, more than a battalion's worth of Belgians were helping to secure the frontier together with 150 rifles of the NRP. ${ }^{10}$ While militarily necessary, this development, mirrored by similar offers of assistance by the Portuguese, was not viewed favourably by the Colonial Office; it recognised the threat posed by the Germans, but was determined to avoid calling on external support unless absolutely vital. ${ }^{11}$ Nevertheless, as the office with responsibility for the raising, controlling and funding of local defence forces, it had to find a workable solution. With the heavy fighting in Europe, the War Office could provide no extra troops while the Colonial Secretary was determined to retain control of the operations. ${ }^{12}$

In May, the Belgian and British governments approved a plan to send Royal Navy motorboats overland from South Africa to attack the Germans on Lake Tanganyika. This was intended to relieve the pressure on Northern Rhodesia and Congo, but would take at least seven months to come to fruition. ${ }^{13}$ It was, however, a substantial German raid against the post of Saisi, north of Abercorn, in late July 1915 that raised the temperature. Threatened with increasing German activity, the Colonial Office was forced into action, as it authorised the raising of 300 men from Rhodesia as well as inveigling the South African (SA) government into raising a contingent of 1500 for service in the region. ${ }^{14}$

By the end of the year, British policy towards Africa was in considerable flux, with some ministers and senior officers working surreptitiously to overturn Lord Kitchener's defensive policy there. Despite the former's strong opposition, the Cabinet formally agreed to the invasion and ultimate conquest of German East Africa to start early in the following year. The bulk of the additional forces were to be provided by South Africa, which would raise and despatch a substantial expeditionary force to British East Africa. ${ }^{15}$

Lord Buxton, the High Commissioner for Southern Africa, was aware that the forthcoming arrival of the Tanganyika Naval Expedition plus the raising of a Rhodesian contingent would increase British military power significantly. Equally, he was concerned about keeping relations with the Belgians harmonious and proposed that a senior British officer for Northern Rhodesia and Nyasaland should command both countries' troops in the region. ${ }^{16}$ These concerns forced the hand of the Colonial Office and on 13 October 1915, the Secretary of State, Andrew Bonar Law, requested the War Office to supply a suitable candidate. ${ }^{17}$ However, owing to external events, it was not until the end of November, that an officer could be chosen as the commander of the regional forces. ${ }^{18}$ 


\section{Brigadier General Edward Northey}

The man selected for this new appointment was a little-known infantry officer, Brigadier General (Brig. Gen.) Edward Northey, lately of the King's Royal Rifle Corps (KRRC). ${ }^{19}$ Aged 47 in 1915, he was a clergyman's son, educated at Eton and Sandhurst before joining his regiment in 1888. He was posted to $1^{\text {st }} \mathrm{KRRC}$, served in India, and subsequently fought in several frontier campaigns before being promoted to captain in 1895. He served throughout the whole of the Second Anglo-Boer War, receiving two mentions in dispatches. On return to Britain, he was then posted as the adjutant of a Volunteer Battalion and gained experience of dealing with non-regular soldiers. He returned to the First Battalion in 1904, and his career continued to go well, being appointed as major and then in 1911, as lieutenant colonel and commanding officer. ${ }^{20}$

Three years later, he led $1^{\text {st }}$ KRRC to France as part of the British Expeditionary Force and took part in the retreat from Mons as well as the heavy fighting on the Marne, the Aisne and $1^{\text {st }}$ Ypres. Northey conducted himself well, being mentioned in despatches. However, on 27 September 1914, he was wounded by a German bullet, as he helped to repel an attack on his battalion headquarters, and was evacuated to the rear. Just more than two months later, he had recovered and was back in command of his unit in the front line. ${ }^{21}$ Northey's efforts were recognised in February 1915 with the receipt of a brevet colonelcy and appointment as an extra aide-de-camp to the King. This was quickly followed by appointment as a brigadier general and the command of $15^{\text {th }}$ Infantry Brigade on 2 March. Joining his new brigade in the trenches near St Eloi, his presence was quickly felt:

Brigadier visits trenches and finds very much work to be done; Parapets too high and not bullet proof, no loopholes for snipers. Very hard work put in; trenches improved \& approaches; support \& communication trenches constructed. ${ }^{22}$

This was to be characteristic of Northey's command style; he visited the front frequently, casting an expert eye over his troops and their work. His energy was to prove critical as less than two weeks later, $15^{\text {th }}$ Brigade was engaged in the heavy fighting around 'The Mound', suffering over 800 casualties in a month. In April, his thoroughness and preparations paid off in the successful attack on Hill 60. Throughout the spring of 1915, Northey and his brigade had their fair share of privations in the trenches interspersed with hard fighting. However, by late June, his forward style brought him into contact with the enemy and he was shot through the thigh while discussing the digging of a new communication trench with the brigade major. ${ }^{23}$

Chance now played its part in determining his future. Again recovered, on the day that his medical board report arrived on the Military Secretary's desk in London, so did a letter from the Colonial Office asking for an experienced officer to command the troops in Northern Rhodesia and Nyasaland. Initially seeming like banishment to a remote theatre, Northey soon realised that he had been given an independent command that would give full scope for his initiative. ${ }^{24}$

It was an intriguing choice, for although he was a highly experienced soldier, apart from his time in command of $15^{\text {th }}$ Brigade, Northey had spent 28 consecutive years at regimental duty. He had neither the staff experience nor training that might have brought him to greater attention. But, unlike some contemporaries, he had not been stultified by the narrowness of regimental life. His was a quick and original brain that was open to new ideas while he had a pleasant and likeable personality. Northey had a quiet and unassuming manner that was tempered by iron resolve and determination. This was matched by an even temper and a concern for his subordinates that caused others to hold him in high regard. In short, he was a capable and brave officer who always looked after those under his command. ${ }^{25}$ 


\section{Preparations for the offensive}

With London's priorities now firmly focused on the offensive through a combined British-Belgian invasion of German East Africa, Northey's mission was adjusted to reflect the new policy. His main task was to secure Northern Rhodesia and Nyasaland from attack, with instructions to assist the naval operations on Lake Tanganyika as well as attack the Germans from the south. ${ }^{26}$ With optimism that the Schutztruppe would be easily defeated and the whole of German East Africa quickly overrun, little thought was given to the coordination of the military effort. Northey therefore remained under the orders of the Colonial Secretary rather than the War Office, with Smuts' authority limited to the main force. The perils of divided responsibility had been amply demonstrated by the disaster at Tanga nearly a year earlier, but Lord Kitchener continued to evade taking on the responsibility that rightly belonged to the War Office. It made no sense to have one force under the Colonial Office, which lacked both the expertise and resources to direct military operations, while the War Office (which did have that expertise and resources) controlled the other, much larger East African Force to the north. Fortunately, Northey had the personality and strength of character to satisfy both.

The commander of Norforce got off to a good start as he journeyed to the front. Stopping in South Africa, he made a favourable impression on the Governor General and High Commissioner, Lord Buxton:

General Northey came and stayed with me on his way to German East. I liked him particularly, and I think a very excellent selection has been made, for it is obvious that, apart from his military gifts, he is a man of great tact and will get on well with the various people with whom he will come into contact. $^{27}$

Northey then spent a week conferring with the government, calling on both Generals Botha and Smuts, before moving north to Southern Rhodesia to meet the Administrator. There, he devoted three weeks to the organisation of the lines of communication from the railway terminus to the northern frontier. He then moved on to Portuguese East Africa, where he met the Governor General and made arrangements for the passage of his troops and supplies through his territory. He arrived in Zomba in Nyasaland in late January, where again he stayed for a fortnight to sort out the supply and transport system from the River Zambezi to the front. The essential preliminaries complete, Northey only reached the forward post of Karonga in northern Nyasaland on 16 February, nearly two months after leaving Britain. ${ }^{28}$

Northey made full use of his professional experience as he grasped, unlike the military amateur Smuts, the vital importance of making adequate logistic preparations before even considering an advance in a tropical country. ${ }^{29}$ His task would be an exceptionally difficult one owing to the limitations imposed by geography and climate in a region that was almost completely undeveloped. In contrast to

British East Africa, there were very few settlers or officials to support the forces or to organise indigenous African labour.

The challenges of conducting successful military operations in thinly populated and undeveloped regions of Africa had long been recognised. While mobile columns could live off the land to some extent, this required operating in populated areas and during seasons of plenty. But with subsistence agriculture, such methods could not be maintained for extended periods or with large numbers of troops as they would quickly eat all the local inhabitants' food supplies. Furthermore, key items such as ammunition, weapons, spares, fuel and technical equipment could not be obtained locally and had to be brought forward. Health was compromised by endemic tropical diseases, notably mosquito-borne malaria and tsetse fly-borne trypanosomiasis ('sleeping sickness'); the former caused tremendous debilitation and suffering for humans, while the latter invariably killed all domestic livestock, including 
horses and mules. A railway and one navigable waterway existed, but were not conveniently located to support military operations. This meant that, prior to the advent of the motor vehicle, military forces were dependent on hired civilian labour, known as carriers, to move all loads (normally carried on the head) with their columns. Carriers were not soldiers and normally operated within a fixed radius of their homes although they could be engaged for prolonged operations. However, this made desertion more likely. ${ }^{30}$ Finally, matters were made more difficult by the extremes of climate that ranged from tropical monsoons to arid desert winds across widely varying terrain and vegetation.

\begin{tabular}{|lcl|}
\hline Segment & Distance in kilometres & Mode of travel $^{31}$ \\
\hline Durban - Beira & 1235 & Ocean steamer \\
Beira - Chinde & 230 & Coastal steamer \\
Chinde - Chindio & 195 & Stern-wheeler \\
Chindio - Blantyre & 280 & Railway \\
Blantyre - Zomba & 70 & Lorry \\
Zomba - Fort Johnston & 130 & Carriers (later cars) \\
Fort Johnston - Karonga & 485 & Lake steamer \\
Karonga - Mwaya & 35 & (steamer directly to Mwaya) \\
Total & $\mathbf{2 6 6 0 ~ k m}$ & \\
\hline
\end{tabular}

Table 1: Norforce lines of communication

In addition to these challenges, Norforce also faced the extremes of distance as its lines of communication began in South Africa at the east coast port of Durban where ocean-going ships took on cargo and sailed to Beira in Portuguese East Africa. From there, coastal steamers steamed to Chinde at the mouth of the Zambezi River. There, personnel and stores were cross-loaded to paddle steamers that moved up river to Chindio where they were landed for the rail journey to Blantyre. Between Blantyre and Zomba, movement was carried out by trucks until the end of the motor road. Carriers were then required to carry stores to Fort Johnston on Lake Nyasa (Malawi) where it was shipped by steamer to Karonga (and later Mwaya). This meant a journey of 715 kilometres from the railhead just to the rear boundary of the operational area; the alternate land route through Southern Rhodesia to the railhead at Broken Hill was even longer at 970 kilometres to the frontier.

To put these distances in context: British doctrine for a developed theatre foresaw the use of a railway line to move supplies from a base to a railhead where the supplies would be transferred to mechanical transport columns, which would then transport the loads to divisional refilling points a maximum of 72 kilometres distance. From the refilling points, divisional horse-drawn train transport would move the supplies a maximum of 24 kilometres to unit quartermasters' stores where its first-line pack animal transport would make the final distribution to the forward troops. In terms of units, this meant that the lines of communication would provide a divisional motor transport (MT) column (45 three-ton and 16 three-hundred weight lorries) to each unit which in turn would have four horse transport train companies (378 horses, 17 carts and 125 wagons) to support the artillery, and another three for its constituent brigades as well as ammunition columns for the artillery. Furthermore, this system envisaged the provision of the full panoply of rear services, including motor ambulance convoys, ambulance trains, clearing, stationary and general hospitals, ammunition and ordnance parks run by the Quartermaster General and Inspector General of Communications. ${ }^{32}$ As an independent force in a remote theatre, Norforce would have been entitled to a much greater slice than a normal brigade; the reality was that in late 1915, there were a total of three 8-ton lorries and no horse-drawn transport with 
carriers doing the work in the forward zones. The challenges were clear: Northey would have to improvise a system to meet such exceptional challenges. ${ }^{33}$

With the all-important base organisation sorted out, the state of the fighting troops now required his attention. Conducting a tour of the entire frontier between Lakes Nyasa and Tanganyika, in which he walked some 880 kilometres (and swam a number of rivers), Northey looked hard at his new command. ${ }^{34}$ The troops were willing, but there were weaknesses in unit leadership and training. Most worryingly, commanders showed little understanding of the realities of modern warfare with their tactics being thoroughly outdated. With only a small staff, Norforce's commander had to devote much of March 1916 putting the defences in order and preparing for the advance with the building of roads and telegraphs to link his isolated garrisons. Considerable effort was also put into the education of his column commanders and the production of detailed tactical instructions. With his experience from the Western Front, Northey knew the importance of thoroughly and methodically preparing his force for battle. ${ }^{35} \mathrm{He}$ issued comprehensive instructions and stressed proper preparation:

Every little detail must be thought out beforehand; transport, supply, ammunition, bombs, entrenching tools ... Remember that an accurately timed concentration from exterior points on to a central object is one of the most difficult in time of war, especially so in a closely intersected bush country. ${ }^{36}$

He understood that in such a vast country with relatively small numbers of troops on both sides, columns would have to operate independently, often widely separated, and reliant on runners and on the few, bulky wireless sets to maintain contact with their commander. He also knew that mobility depended on having sufficient carriers to carry supplies forward, and he arranged for thousands to be recruited through the colonial governments in Nyasaland and Northern Rhodesia. ${ }^{37}$ Initiative and good judgment would be at a premium making it fortunate that he had two high-quality column commanders in the persons of Lieutenant Colonels (Lt. Cols.) GMP Hawthorn of $1^{\text {st }}$ KAR and RE Murray of the British South Africa Police (BSAP), commanding in Nyasaland and Northern Rhodesia respectively; both of whom would play leading roles in the coming advance. There were also some less talented officers, but with few resources, Northey had to make the best possible use of the available manpower.

All in all, Northey's appointment would demand strong leadership, courage and a steady nerve together with a mastery of staff work, both operational and administrative, under the most difficult of physical conditions. It was a challenge that would make great demands of his force over the next two and a half years.

\section{The advance into German East Africa: May-August 1916}

General Smuts' main advance had begun in March 1916, but as the rainy season finished later in the south, it was agreed that Norforce would begin its advance in late May. Apart from allowing the ground to dry out, it was hoped that the staggered start might also draw off German reserves to the north. Physically separated by hundreds of kilometres, communications between Smuts and Northey were limited to a circuitous telegraphic route with little prospect of direct discussions.

The extra time was welcome as most of the fighting units were newly raised and all required additional training in modern warfare. They were drawn from very mixed backgrounds: at one level was the regular $1^{\text {st }}$ KAR, followed by the paramilitary BSAP and NRP, veterans of the South-West Africa campaign in the $5^{\text {th }}$ Mountain Battery, South African Mounted Rifles (SAMR), down to the newly recruited $1^{\text {st }}$ and $2^{\text {nd }}$ South African Rifles (SAR). Overall, there were about 2400 effective rifles in the theatre, divided into four columns. Facing them, were an estimated 1500 enemy rifles deployed along the frontier, with the bulk concentrated in Bismarckburg in the west and Neu Langenburg in the east. In fact, 
the German numbers were considerably overestimated, with only 700 available and highly dispersed. They too, suffered from inadequate communications, lacking direct telegraphic links to the main body and were served by unimproved footpaths rather than roads. ${ }^{38}$

General Northey set himself an ambitious plan, as he wanted to clear the northern border in a single stroke. He deployed the bulk of his strength in the east with three columns concentrated between Fife and Lake Nyasa, while his fourth column under Murray was far to the west around Abercorn. The plan was to advance rapidly and cut off the German line of forward posts, forcing them to surrender. This hinged upon moving rapidly and striking before the enemy could react. The extremely low density of troops and the considerable size of the area of operations offered great opportunity for manoeuvre, but would also require concentration at key points in order to avoid defeat in detail. Northey also had the advantage of command of Lake Nyasa, where, with the seven small steamers and several well-located ports, he could quickly move troops and supplies over a hundred kilometres in a couple of days. ${ }^{39}$

Starting on 23 May, the advance into German East Africa began well. The independent columns quickly reached and encircled their objectives. Rather than directly assaulting the very strong defences, the besiegers moved to cut off any escape. However, these moves had been partially forestalled by the enemy commander's decision to start withdrawing north. Northey and his troops were soon to learn the difficulty of preventing determined troops from exfiltrating through a loose cordon in densely vegetated country at night. Consequently, after suffering a number of casualties, the surrounded garrisons managed to break out, albeit in some disorder, and with the loss of much equipment and supplies. By 29 May, Norforce was in possession of the principal border posts and pursuing the disorganised Schutztruppe closely. ${ }^{40}$

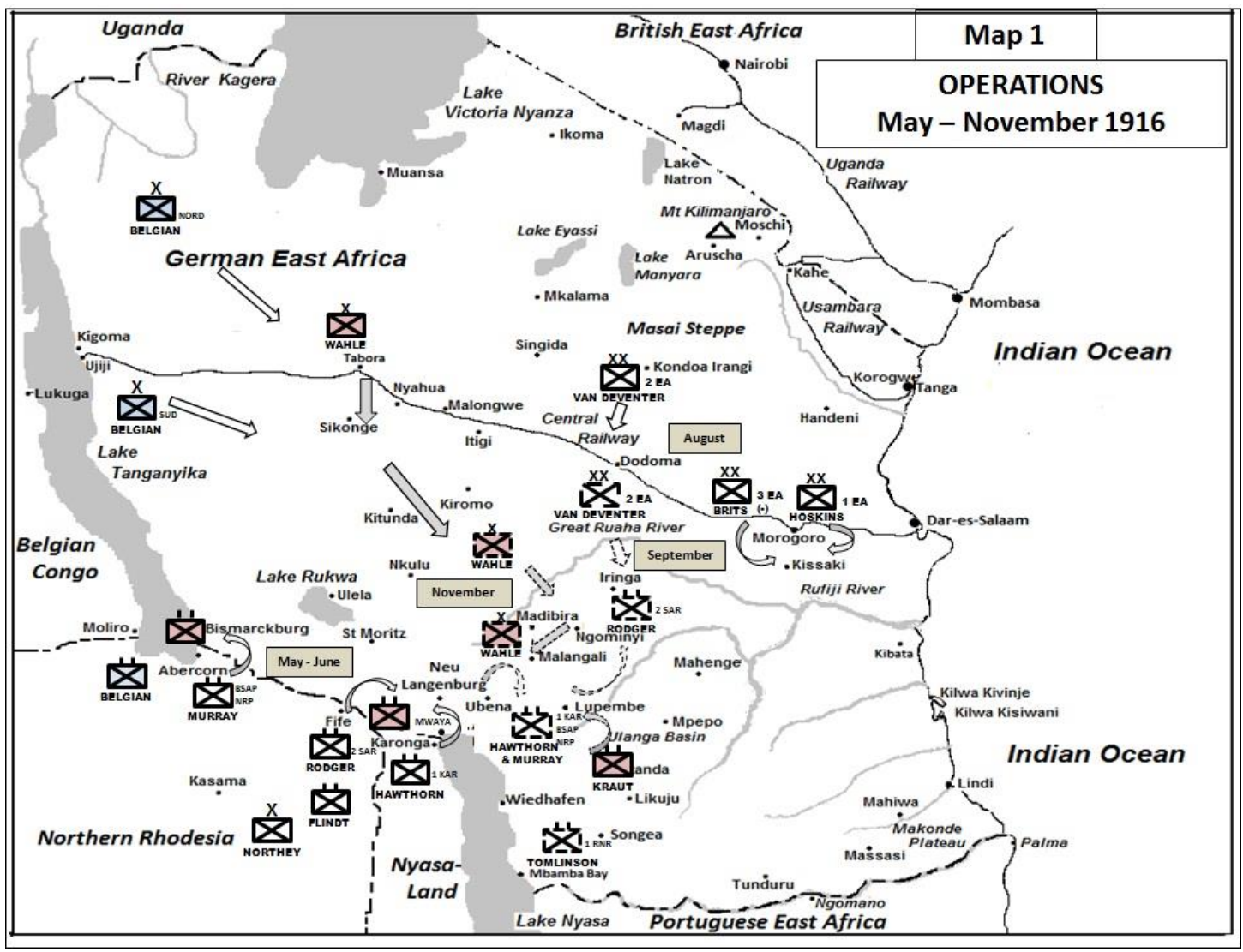

Map 1: Operations in German East Africa (May-November 1916) 
The leading columns had advanced up to 130 kilometres through difficult terrain and across swollen rivers in less than five days. With crossroads and district capital of Neu Langenburg now captured, Northey kept pushing his columns forward in an effort to cut the Germans off. In the west, the enemy near Bismarckburg remained encircled by Murray's Rhodesian troops, only breaking out with considerable loss on 5 June. The Germans were in disarray and unable to offer an effective defence against the attackers; they also suffered heavily from desertions by both carriers and armed auxiliaries.

On 10 June, Norforce was forced to pause, having advanced up to 240 kilometres in just more than a fortnight and with its two main groupings some 320 kilometres apart. Northey now turned his attention to the new lines of communication between Neu Langenburg and Mwaya, at the northern end of Lake Nyasa, so as to make best use of his steamer flotilla. He also ordered the improvement of the existing tracks as well as the laborious process of stockpiling supplies. ${ }^{41}$

He had reason to be pleased, as the advance had secured the borders of Northern Rhodesia and Nyasaland from the threat of invasion while disrupting the enemy thoroughly. Casualties had been very light, numbering fewer than twenty, while the local African population was proving very helpful. ${ }^{42} \mathrm{On}$ the other hand, Northey had not achieved the decisive results he had desired as both he and his troops grappled with the realities of bush fighting. Nevertheless, it was a most promising start and his troops had full confidence in him.

\section{The advance to Iringa: June to September 1916}

Although nominally independent, Northey always remained conscious of the need to support General Smuts's main advance. As the main force neared the Central Railway, Smuts hoped to surround the Germans in the heart of their colony, ringed in by the Belgians and Norforce. He planned to send Van Deventer's Second Division south from Kondoa Irangi towards the Great Ruaha River while bringing up Norforce to link up from the south to cut off the enemy Westtruppen who were being pushed east out of Ruanda and Urundi by the Belgians. To the south and east of Lake Tanganyika, the 480 kilometres to Bismarckburg was very sparsely populated and unlikely to support any sizeable German force. Together with the success of the British-Belgian naval flotilla in dominating the waters of Lake Tanganyika, the western flank was no longer a significant concern and Norforce could be concentrated for the drive on Iringa.

The eastern flank was rather more challenging as the escarpment fell dramatically into the steamy lowlands of the Ulanga valley. Here, the thick bush and many watercourses presented obstacles to movement while the Schutztruppe maintained a number of weak detachments to protect the approaches to the important Mahenge plateau. More importantly, the British established supply depots at Iringa, Mahenge and Kissaki for the sustenance of troops south of the Central Railway. ${ }^{43}$ Further to the south and east of Lake Nyasa, lay the Songea district, a fertile and valuable area rich in food that was virtually undefended. Northey had consistently, but unsuccessfully, tried to get the Portuguese to occupy this area to protect his right flank as well to deny it to the Germans. Northey rightly worried about the vulnerability of his small force, dependent as it was on long and exposed lines of communication.

He was also personally keen to maintain the pressure, and agreed to move north in early June although the Second Division would be unable to start for at least three more weeks. His objective was Iringa, some 430 kilometres north of Neu Langenburg along the spur of the Utschungwe (Udzungwa) Mountains, which extend from Lake Nyasa in the south to Iringa, rising to a peak of 2579 metres. ${ }^{44}$ On 8 June, Murray was ordered to rejoin the main body from Bismarckburg by a 320kilometre march to Neu Langenburg, a journey that would take some three weeks. ${ }^{45}$ 
Smuts' plan looked good on a map, but overlooked the reality that Iringa was 80 kilometres from the Great Ruaha River, which in turn lay some 120 kilometres from the Central Railway on which the Second Division would have to depend. Furthermore, it would not be easy to trap the Schutztruppe in such an area of thick vegetation and difficult terrain. Despite these concerns, Northey began planning for the move on Iringa using his headquarters at Neu Langenburg. From this hub, tracks radiated to Iringa, Mahenge and Songea, all key centres of population and agriculture.

The Utschungwe range, especially around Iringa, was wild and thickly forested, connected by a few steep and winding tracks. The ground then fell off sharply at the escarpment near Lupembe where it dropped into the low-lying land of the Great Ruaha and Ulanga River basins that ultimately joined that of the Rufiji River further east. Along the north-eastern edge of Lake Nyasa were the Livingstone (Kipengere) Mountains that form part of the escarpment of the East African Rift, extending about 100 kilometres down the north-eastern shore to the Ruhuju River. Owing to this combination of broad, flat valleys surrounded by steep mountains and massifs, flooding was extensive during the rains. This meant that the Rufiji River could expand from a width of 400 metres in the dry season to nearly 10 kilometres between banks during the wet season. The Great Ruaha and Ulanga Rivers were not as dramatic, but the flooding was still very extensive. There were no roads with only footpaths leading from village to village. The numerous rivers and streams were surrounded by dense jungle, high grass and swamp. These lowlands were hot, humid and pestilential with vast numbers of malarial mosquitoes and other pests that made life a misery and spread the many prevalent tropical diseases.

By contrast, the German-held Mahenge Plateau that rose above the Ulanga and Rufiji Rivers was fertile with a relatively healthy climate and substantial population. An attractive objective, Mahenge was protected by the surrounding humid forest and difficult tracks that led through the lowlands. Further to the south-west was the district of Songea, which was better drained and equally fertile. It had the advantage of being much more easily accessible, as vessels on Lake Nyasa could easily steam from Mwaya down to the small port of Wiedhafen (Manda) before marching inland. ${ }^{46}$

Overall, the climate in the highlands was wet, although much cooler and less trying than the torrid lowlands. Neither area was, however, heavily populated nor developed. Supplying a large force would be almost impossible under the existing conditions, and improvements were essential. Northey now turned to his sole squadron of SA Engineers, who numbered barely 50 sappers, to begin a major road-building programme. They were assisted by large numbers of local African labourers who did much of the physical labour of hacking out routes. Equally important was the expansion of the transport service needed to move supplies forward to the troops. Although there were a few motor vehicles available, these had only limited utility in the forward areas, and the vast majority of loads were carried on the heads of African carriers. If this was one of the least efficient methods of transport, it was essential in the absence of railways or motor vehicles, themselves in their infancy. This, plus the enormous distances involved, meant that vast numbers of civilians were required to support the columns.

Colonel Hawthorn with $1^{\text {st }}$ KAR cleared the area around Neu Langenburg, occupying the key crossroads at Ubena (Njombe) on 18 June while another column secured Brandt, seizing tons of supplies. The SA Engineers had extended the new motor road from Mwaya to Neu Langenburg to Brandt, enabling the vastly more efficient motor vehicles to relieve the porters who in turn could move forward with the marching columns. The extra supply capacity also meant that Murray's BSAP column could be sustained in the forward area as it duly arrived at the end of June. ${ }^{47}$ Now, with reports of the German reinforcements arriving from the north, Northey could prepare his force for the next stage of operations.

On the German side, Col. Lettow was concerned about the threat posed by Norforce's advance towards the southern granary of the colony. Unwilling to sacrifice most of the wheat crop, he ordered substantial reinforcements in late June to march south from the Central Railway and Iringa to hold the 
general arc Madibira-Malangali. These villages were about 70 kilometres apart, both being about 240 kilometres north-east of Neu Langenburg, and lie astride the route to Iringa. With more than 800 additional rifles on the march, the local Schutztruppe would soon pose a serious threat to Norforce. ${ }^{48}$

By mid-July, Northey estimated that there were now more than 1100 Germans entrenched to the north of his force. A new danger now emerged from the east in the form of Abt. Kraut appearing at Lupembe. With his right flank at Ubena threatened, Headquarters (HQ) Norforce ordered Hawthorn's $1^{\text {st }}$ KAR to deal with Kraut. But, despite his repeated entreaties, Northey was deeply disappointed by the failure of his Portuguese allies to send troops to the Songea area, which was only lightly held. ${ }^{49}$ The detachment of $1^{\text {st }}$ KAR now meant that there were only about 1000 rifles available for the planned move on Iringa.

It was not until the third week of July that Norforce was again ready to attack to the north. As there were nearly 900 enemy troops holding Malangali, Northey decided to use the bulk of his troops to attack there, leaving Murray with a small covering force at Madibira. A concentric advance succeeded in dislodging the defenders at heavy cost while the British had 80 casualties, the bulk of whom were lightly wounded. It was an important victory, as it forced the evacuation of Madibira and the Germans retired north along the Iringa road. ${ }^{50}$

Unfortunately, this success was not matched by similar progress in the north as the weakened Second Division was only now just beginning to advance from Kondoa Irangi while the main body was halted further east on the Lukigura River suffering badly from inadequate supplies. The planned link-up between Smuts and Northey was still far from being effected, and Norforce was becoming increasingly exposed from both the German forces in the far west being pushed eastwards by the Belgians and the smaller force at Lupembe. Some reinforcements in the form of recruits for $1^{\text {st }}$ KAR and the recently raised $1^{\text {st }}$ Rhodesian Native Regiment $\left(1^{\text {st }} \mathrm{RNR}\right)$ were on their way, but they were barely trained and unready for use..$^{51}$

By the beginning of August, and despite repeated assurances, it was also clear that no reliance could be placed on the Portuguese securing Songea. With orders to hold firm for the moment, Northey decided to send Hawthorn's column to deal with the enemy around Lupembe, while leaving Murray and Lt. Col. Rodger of $2^{\text {nd }}$ SAR to hold in the north. This move soon had the desired effect, and Norforce could resume its drive north. ${ }^{52}$

In the meanwhile, Second Division had reached Kilossa on the Central Railway and a link-up again appeared possible. Columns under Cols. Murray and Rodger were now instructed to push north towards Iringa. Resistance was light with the Germans conducting a delaying action and avoiding decisive action. By 29 August, the highlands were clear and Iringa was occupied. It was another remarkable advance in difficult conditions and on the very limits of supply. Nevertheless, a gap of nearly 160 kilometres of dense jungle remained between the two forces.

On the other hand, it left Northey's troops in a very exposed position as they were dependent on a fragile line of communication of more than 320 kilometres and with no flank protection. Apart from Kraut in the east, a much more worrying development was the withdrawal of the substantial German forces under Gen. Wahle from Tabora. It was likely that they would attempt to march on Mahenge in order to rejoin the main body of the Schutztruppe. Such a move would pose a major threat to Northey, especially as his forward bases at Ubena and Buhora were virtually unprotected. He simply lacked the troops to be strong everywhere.

Smuts was less concerned and wanted Norforce to seize Mahenge, another 160 kilometres to the east of Iringa. Northey had considered this previously, but had rejected the idea as too risky as he was concerned about being cut off and urged that the Second Division move to Iringa to enable him to 
concentrate his scattered troops ${ }^{53}$ The short rainy season was due to start anytime and this would further complicate supply matters. ${ }^{54}$ Smuts ignored these blandishments, and in early September gave orders for the advance. These were soon followed with instructions to occupy the rich Songea district. Northey had no choice but to commit his only reserve, the newly raised $1^{\text {st }}$ RNR, under Lt. Col. Tomlinson. Half the battalion sailed by steamer to Wiedhafen in mid-month, reaching Songea on 20 September. ${ }^{55}$ Norforce was now truly over-extended with Roger and Murray around Iringa, Hawthorn at Lupembe and a third force at Songea. It now numbered about 4700 of all ranks, of whom about 3700 were fighting troops. The lines of communication remained paramount as Hawthorn at Lupembe had to be supported over a distance of more than 320 kilometres of difficult mountain, forest and lowland valley back to the main body which was another 288 kilometres back to Mwaya on Lake Nyasa. Songea was relatively easy as supplies could move by steamers to Wiedhafen, but there remained some 119 kilometres to move overland. ${ }^{56}$

Concurrent with the occupation of Songea, Hawthorn moved forward to Mkapira on the Ruhudje River where he successfully engaged Abt Kraut. Murray then marched south to join him at the end of September where both prepared for the planned advance ${ }^{57}$ If Norforce was ready, then Second Division was manifestly not, and the offensive had to be postponed indefinitely. Instead, the columns prudently prepared defences and built up food stocks, ready for any counter-attack. ${ }^{58}$ Now deploying nearly 4000 rifles in three detachments separated by wild and mountainous terrain, Northey was growing increasingly nervous about the progress of Wahle's troops. They had disappeared from view south of Tabora on 19 September and were believed to have 1500 rifles (in fact they had 2 500). Together with Kraut's 2400 rifles in the east, the Germans posed a grave danger to Norforce. Despite the seriousness of the situation, the Second Division could only despatch an understrength mounted squadron to the Great Ruaha River, which was still 115 kilometres north of Iringa. ${ }^{59}$

Wahle's troops appeared near Iringa on 12 October and began building up for an attack. ${ }^{60}$ The Second Division ordered a weak battalion south, but with Hawthorn and Murray faced by a strong force under Kraut, they could not come to Rodger's assistance. ${ }^{61}$ The lines of communication had only tiny garrisons at the major depots and Northey now committed his only reserve, the remaining half of $1^{\text {st }}$ RNR, to his transport base at Buhora and waited. ${ }^{62}$ The cutting of telegraph wires to Iringa soon deprived him of personal influence on the coming battle.

By 22 October, Wahle was ready to attack the beleaguered garrison of Iringa while Kraut had begun to surround Hawthorn and Murray in the south. ${ }^{63}$ The situation appeared bleak and was saved by the arrival of a weakened SA infantry battalion from the north. However, it was just sufficient to disrupt Wahle's attack and to persuade him to move south against easier targets. ${ }^{64}$ For their part, Hawthorn and Murray were well dug-in and had accumulated sufficient food for a determined stand. ${ }^{65}$

Thwarted at Iringa, Wahle overran the supply depot at Ngominyi on 28 October before moving on to the major base at Malangali. ${ }^{66}$ Northey made use of his wireless transmitter to inform Hawthorn and Murray of the desperate situation. That night, they launched a surprise attack that drove Kraut back across the river with heavy losses. Now free to move, Northey ordered Murray to march back to deal with Wahle. ${ }^{67}$ At long last, the bedraggled Second Division was able to move to Iringa, taking command on 30 October, and relieving Norforce of a major burden. ${ }^{68}$

Wahle's leading troops reached Malangali on 8 November. Apart from its vital supply dumps, its loss would also leave Buhora, with the bulk of Norforce's vehicle transport fleet, at great risk. With the defenders greatly outnumbered, Northey decided to make a daring counter-move. He used 50 of his scarce light cars to carry half of Murray's troops to relieve the besieged depot, making good use of his road network. It was a gamble, but the 304-kilometre road move was a success as his arrival induced 
Wahle to break off the attack. On the night of 11/12 November, Murray completed his mission by completely overwhelming the German rearguard. ${ }^{69}$

Wahle now moved on towards Lupembe, but Norforce had regained its balance. Murray's Rhodesians re-embarked in vehicles and returned to secure the vital crossroads at Ubena, while Murray ordered Hawthorn to march back on Lupembe..$^{70}$ Then both columns converged on the besiegers and broke the encirclement. By 15 November, Wahle's troops had disappeared to the east where they joined up with Kraut in the Ulanga valley. Once again, Northey had used his resources to excellent effect as his engineers continued to make new roads to head off the enemy, and he used his vehicles to move 200 or 300 men on a regular basis. ${ }^{71}$

However, the battle was not quite finished, as Songea was next to face attack by the Germans on 12 November. The raw half-battalion of $1^{\text {st }}$ RNR held it off, inflicting heavy casualties on the attackers who then withdrew eastwards to Likuju. ${ }^{72}$ At the same time, one of Wahle's columns had become separated and had straggled badly behind the main body. Nearly 300 strong and armed with a howitzer, these troops halted at Ilembule on 20 November, unaware of the location of the main body. Once again, Northey used his wireless communications and superior mobility to deal with the threat. Murray's column moved out in vehicles, surrounding the detachment and cutting them off from water. Within a few days, they were forced to surrender. With this capitulation, the threat from the west had completely passed. ${ }^{73}$

The fighting also obscured an important change to Norforce's status. On 14 November, it was removed from Colonial Office control and formally subordinated to the Commander-in-Chief (C-in-C), East African Force. Although this was a nominal loss of independence, in practice it meant little change as Northey had always acted as though he was under General Smuts's orders. Equally, he retained full responsibility for running his own supply and administration. ${ }^{74}$

The threat to Norforce had been very real, and Wahle missed a chance to destroy his opponent's exposed lines of communication or even headquarters. Northey's exposure was partially due to his risk taking, but also to Smuts's lack of understanding of the threat. Nevertheless, Northey had recovered well and his tactics, helped by dynamic column commanders, had ensured that a potentially dangerous blow was successfully parried. His attention to his lines of communication had also paid off tactically, as it enabled him to risk his small fleet of motor vehicles in a bold counter-move. Having inflicted more than 500 casualties onto an enemy possessing the advantages of concentration and tactical freedom, Northey had salvaged a minor victory out of likely defeat. ${ }^{75}$

Nevertheless, the arrival of Wahle's troops more than doubled the size of the Schutztruppe in the region. That officer now took command of the troops west of Mahenge, while a considerable detachment under Kraut remained near the eastern edge of the escarpment with another under Wintgens further to the east at Gumbiro. The rains were wreaking havoc on the lines of communication as rivers flooded and roads dissolved into mud. Both sides were now worn out after the exertions of the past six months and needed time in which to gather supplies and rest the troops. ${ }^{76}$ An operational pause ensued and reorganisation was set in train. But the results of the advance had not gone unnoticed in South Africa:

Northeys [sic] success is very cheering ... He has indeed done good work with his small force, and difficult communications, and if we had sent him a larger number of our own natives it would go hard, but he would finish the lot off. ${ }^{77}$

Smuts's troops further north were in terrible condition, suffering heavily from underfeeding, overexertion and malaria. His nominal divisions were in fact individually weaker than Northey's 5000 rifles and unfit for further offensive operations. ${ }^{78}$ For its part, Norforce was also suffering heavily from sickness although it never lost its cohesion and effectiveness owing to strong leadership and good organisation. 
These qualities would soon be required again for a renewed offensive. By 13 December, Northey estimated that only 72 kilometres out of the 560 kilometres of motor roads were usable. This meant that all supplies now had to be carried laboriously by porter from Lake Nyasa over the Livingstone Mountains before going forward. ${ }^{79}$

General Smuts was never less than ambitious in his planning. Anxious to wrap up the campaign, he planned a renewed general advance for late December 1916. In the east, his troops would push west and south towards the Rufiji River while the Second Division would move in from the west. For its part, Norforce was to clear the Iringa highlands of the enemy before moving east towards Mahenge. It was a grand plan that rested more on hope than on sound planning, but Northey was a dependable subordinate who could be relied upon.

Norforce began its advance against Kraut's troops on 24 December only the next day to find the position evacuated. Despite supply problems, the troops pushed on and by 9 January 1917, the escarpment was clear with Kraut well to the south. Northey shifted Murray's column in pursuit, while Hawthorn cleared to the Ruhudje River, which now was beginning to flood. Kraut was now trying to move south towards Songea, which was being reinforced by Major (Maj.) Grawert. ${ }^{80}$ On 19 January, the British moved first and surrounded Grawert's troops near Songea. Cut-off and out of food Grawert surrendered on 22 January with more than 230 soldiers and a field gun. This was another notable success and relieved the pressure on Songea. The rain continued to fall and by the end of the month, the rising rivers forced Northey to pull back from the Ruhudje valley and onto the high ground. ${ }^{81}$ It was an excellent achievement as Norforce had fully carried out its orders to drive the enemy into the unhealthy lowlands while capturing another entire detachment intact. The full onset of the main rainy season made campaigning even more difficult than hitherto as both sides had to contend with severe supply problems and just trying to remain alive. Norforce was widely stretched over a vast area of country; the distance from his headquarters in Ubena to the forward troops was 208 kilometres with columns split between Likuju, Songea, Kitanda, Alt-Langenburg and Lupembe. Northey remained dissatisfied with the situation around Songea and at the end of January, he decided to send Hawthorn to take charge there. Concurrently, $1^{\text {st }}$ KAR split itself into two battalions with $1 / 1^{\text {st }} \mathrm{KAR}$ staying put and $2 / 1^{\text {st }}$ being sent south with Hawthorn. ${ }^{82}$

Norforce's superior preparations had enabled it to withstand the effects of the climate better than the main force under Smuts, but sickness continued to take its toll. After the long advance to Iringa and the subsequent fight against Wahle's troops, Norforce needed a rest as the lines of communication were disintegrating in the mud. As the month progressed, the rains became increasingly heavy and the broad lowlands east of the escarpment continued to flood. Although on higher and healthier ground than Hoskins's main body, the troops of Norforce were still suffering from the cold, damp climate and disease. Numbers had been reduced to less than half the normal strength, and the SA units were particularly hard hit by sickness. ${ }^{83}$ However, unexpected events would soon deprive it of any respite.

\section{The Wintgens raid}

The troops commanded by Kraut and Wintgens remained the main worry for Norforce as both were energetic and dependable commanders, but were suffering acutely from a lack of food and were constantly foraging for enough supplies to survive. ${ }^{84}$ Equally, Northey had only a limited number of troops spread over enormous distances. This meant that he could only defend discreet points rather than a continuous line. He was well aware of the impossibility of preventing a breakthrough, but could do little but remain vigilant. By mid-February, his worst fears were realised when Abt. 
Wintgens, with about 550 rifles, made such a break to the north-west. It knifed through the tenuous lines of communication near Gumbiro, overrunning a supply post and threatening both AltLangenburg and Ubena. Northey immediately despatched $1^{\text {st }}$ RNR in pursuit and brought back Murray's column, now reinforced by $1 / 1^{\text {st }} \mathrm{KAR}$, from the forward areas to support them ${ }^{85}$

It was a timely move, as Murray arrived just in time to disrupt Wintgens's plans for an attack. Now seriously threatened, the Germans turned north-west heading for Lake Rukwa, using their head start and superior mobility to break away. Murray had to pause briefly and then followed on, supported by one of Northey's scarce aircraft. Much hard marching followed as they tried to pick up their opponent's trail although they were aided by aerial reconnaissance. Physical contact between the columns was not restored until 11 March as Wintgens headed for St Moritz. ${ }^{86}$ En-route, his Abteilung. trapped the RNR column and Murray was diverted to their rescue from his task of cutting off the enemy's line of retreat. This was successful but Murray's troops they lost valuable time that enabled the Germans to escape.$^{87}$ The Schutztruppe made pursuit more difficult by stripping the countryside bare of food, forcing Murray to bring his supplies forward by carriers. Murray remained in hot pursuit, heading for St Moritz where he believed that Wintgens was trapped behind two swollen rivers. After a number of encounters, the Germans reached their objective on $26 \mathrm{March}$, and began to build improvised rafts. ${ }^{88}$

In the south, Kraut was also causing problems for Northey as the former's Abteilung moved against the vulnerable Wiedhafen-Songea area. Now it was Col. Hawthorn's turn to pursue the highly mobile enemy and he did so vigorously with $2 / 1^{\text {st }}$ KAR. Abt. Kraut was hit repeatedly, but was able to break contact and head for the Portuguese border. On 24 February, Hawthorn was recalled to Songea to be ready to deal with another enemy force, under Captain (Capt.) Lincke, assembling at Likuju, some 80 kilometres north-east. Once again, the lighter German columns, living off the land like locusts, were able to outstrip their British counterparts, who were dependent on lengthening lines of communication. Kraut's force was still on the move and unlocated, but it was presumed to be heading south of the Rovuma. ${ }^{89}$

March saw some welcome developments for Northey as he received the newly raised $1 / 4^{\text {th }}$ KAR from Hoskins as well as the news that another battalion of Cape Coloured (mixed race) men $\left(2^{\text {nd }}\right.$ Cape Corps) and two of Rhodesians were being raised for him. ${ }^{90}$ Hawthorn spent some time reconnoitring the difficult terrain in the Likuju area and driving back enemy outposts. Murray continued doggedly on Wintgens' tail, hitting his rearguards repeatedly, but unable to outpace the main force. Northey kept a close watch on matters:

I have impressed upon Col. Murray the importance of concentrating towards WINTGENS and not allowing WINTGENS to beat him in detail: also to close round so that WINTGENS cannot easily collect food. ${ }^{91}$

If Wintgens remained elusive, Hawthorn's efforts had forced Abt. Kraut to retire in a battered condition to Tunduru for recuperation. Equally worrying was the state of the troops' health, particularly the white South Africans. Both $1^{\text {st }}$ and $2^{\text {nd }}$ SAR were nearly totally unfit for offensive operations while their morale was dented by having to carry on campaigning while the majority of SA units in the north were being sent home. ${ }^{92}$

It was clear that, despite Murray's valiant efforts, reinforcements were required. By the end of March, Gen. Hoskins had dispatched extra troops towards Bismarckburg and Tabora while asking for Belgian assistance. ${ }^{93}$ But the strain on Norforce was almost unbearable with its HQ in Ubena and columns scattered from south of Tabora to Iringa to Songea, the bulk of the 725 kilometres being complete wilderness. Northey noted: 
I do not think that anyone who does not know CENTRAL AFRICA, with all its difficulties of supply and transport, torrential rains at this Season of the year, mountain passes, flooded rivers, and swamps, can appreciate how extraordinarily quickly MURRAY'S Column has moved under the circumstances, from 150 miles [240 kilometres] East of the North end of LAKE NYASA to 100 miles [160 kilometres] North-west of same. ${ }^{94}$

This dissipation of strength placed enormous pressure on Northey's small and overworked supply staff, which also had to make preparations for the forthcoming dry season offensive. The loss of Murray's column had reduced Norforce by more than three battalions, but Abt Kraut still posed a threat further to the south either around Songea or in Portuguese East Africa. ${ }^{95}$ It was a distinctly undesirable position, but in the circumstances, there was little choice.

April was largely taken up with the continued pursuit of Wintgens at ever-increasing distance from Norforce's supply bases. Hawthorn's column left the Songea area to deal with Lincke, reaching the flooded Likuju River on 7 April. After a number of inconclusive skirmishes, he managed to cross the river and move on to the camp at Likuju, occupying it without opposition on 27 April, with Abt Lincke having evacuated to the east. ${ }^{96}$

If this assured the security of Songea, a new threat was arising. Patrols and captured dispatches made it clear that elements of Abt Kraut, under the command of Major (Maj.) von Stuemer, were marching south into Portuguese territory. This was confirmed on 27 April when they occupied Mwembe, some 190 kilometres north-east of Fort Johnston. ${ }^{97}$ This move posed a distinct danger as there was little to stop Stuemer from continuing on through Portuguese East Africa and on to the Zambezi River. This could potentially sever Norforce's vulnerable lines of communication while little assistance could be expected from the poorly trained Portuguese forces. Northey had little choice, but to send his last reserve, the recently formed and barely trained $5^{\text {th }}$ South African Infantry $\left(5^{\text {th }}\right.$ SAI) to Fort Johnston. These troops had been suffering heavily from illness, but there was no other option to plug the gap. ${ }^{98}$

Murray, delayed by supply problems and a lack of carriers, was south of Kitunda on 3 May, just as the enemy completed his escape. ${ }^{99}$ With wet ground and swollen rivers delaying his food convoys, the follow-up north was again broken as his column could not close the gap. However, help was on the way, for the Belgians took over responsibility for Bismarckburg and Tabora while British reinforcements moved up the Central Railway. ${ }^{100}$

In the south, Stuemer's raid was causing increasing worry as it was attracting significant local African support. On 6 May, Northey ordered the newly arrived $1 / 4^{\text {th }}$ KAR from Ubena to Fort Johnston while $1 / 1^{\text {st }}$ KAR was detached from Murray to act as a local reserve from Ubena. At the same time, Northey shifted his HQ from Ubena back to Zomba in Nyasaland in order to be near the greatest threat. ${ }^{101}$

These re-deployments were extremely timely as the troops arrived at their forward border posts just before the Germans got there. With the main route between Portuguese East Africa and Nyasaland firmly guarded and both sides roughly equivalent in numbers, the situation quieted down as each settled into new positions. ${ }^{102}$ Northey reached Zomba on 14 May as his reinforcements began to arrive. With the coming of the rains to Songea, he decided to shift his main effort to Nyasaland and ordered Col. Hawthorn to take local command there. ${ }^{103}$ With an increasing enemy presence in Portuguese territory, it was a timely move as the promised Portuguese reinforcements only reached the seaport of Chinde on 25 May. These were diverted to the protection of the lines of communication leading up to Nyasaland and were kept away from the scene of active fighting. This provided muchneeded protection of each force's supply lines and, as the British desired, kept the two armies 
separated. In any event, with the Portuguese embroiled in the suppression of the revolt further south in Tete and Barue, they could do little more. ${ }^{104}$

In the west, Wintgens had become critically ill and had turned over command to Lt. Naumann on 21 May. Although Murray was still pressing hard from the south, he was plagued with ever-longer supply lines and a lack of carriers. Finally, with the Belgians now fully involved in the pursuit, Murray was ordered to rejoin Norforce on 28 May. Although he had been unable to stop the wily Wintgens, his troops had made an outstanding effort that earned the justified tribute of Gen. Hoskins. ${ }^{105}$ Murray's force, only 80 kilometres south of the Central Railway, now began the long march south, reaching the Ubena area on 15 June where they were given a week's rest before moving on to Mwaya on Lake Nyasa for the coming offensive. The break was well earned as the men had been on the march continuously on short rations and few comforts since February. ${ }^{106}$

On 25 May, the remaining half of $1 / 4^{\text {th }}$ KAR arrived at Fort Johnston, giving Northey local numerical superiority. This enabled him to order patrols into Mtonia the next day, and to capture it on 1 June. The Germans appeared to be thinning out and it was decided to reinforce the advantage south of Lake Nyasa. On 3 June, Northey moved $1 / 4^{\text {th }}$ KAR forward to support the South Africans, while withdrawing the details of semi-trained KAR soldiers back to Zomba where they resumed the vital task of preparing for the forthcoming operations. ${ }^{107}$ With the immediate threat having been averted, Northey resolved to drive the Germans out of Portuguese territory and north of the Rovuma into the developing envelopment being led by the main forces. ${ }^{108}$

By early June, Norforce was widely stretched over a vast area of country; the distance from his HQ in Ubena to the forward troops was 210 kilometres alone, with columns in Likuju, Songea, Kitanda, AltLangenburg and Lupembe. ${ }^{109}$ They were faced by three major groupings with Abt. von Langenn opposite Lupembe, Abt. Lincke near Likuju, and Abt. von Stuemer near Fort Johnston. Additionally, Wahle maintained control over a substantial number of troops based at Mahenge that could easily enter the fray. It was a far from enviable position.

\section{The push into German East Africa: June-November 1917}

General Northey considered that the German main body would only move into Portuguese East Africa if pushed there, and, until the situation east of Mahenge had been cleared up, there was the potential for another raiding force to break westward. He proposed converging simultaneous thrusts against the enemy, but, conscious of the time needed to get Murray's column back and suitably rested, Northey expected that the former's advance would start after the others. The new C-in-C, Gen. Van Deventer, agreed, realising the importance of having Northey attack Mpepo and Mtarika as it would draw off enemy forces on the Ruipa line prior to the arrival of the Belgians. Once the latter were ready, Northey could then shorten his line by giving them responsibility for the Ruhudje sector. By that stage, Murray's column would be able to participate in the general offensive. ${ }^{110}$

This would leave the Songea column at about 1000 rifles with 16 machine guns and two mountain guns, and the Fort Johnston column with a similar number, both ready to start at the end of June with Murray's column preparing until 7 July. This would provide another 1000 rifles, giving Northey more than 3000 men advancing on two axes. The Norforce commander also noted that an additional two battalions' worth of reinforcements would be arriving in July, but neither would be ready for the field before August. ${ }^{111}$ Likuju would also form an important staging base, as both a wireless station and small airfield were established there. 


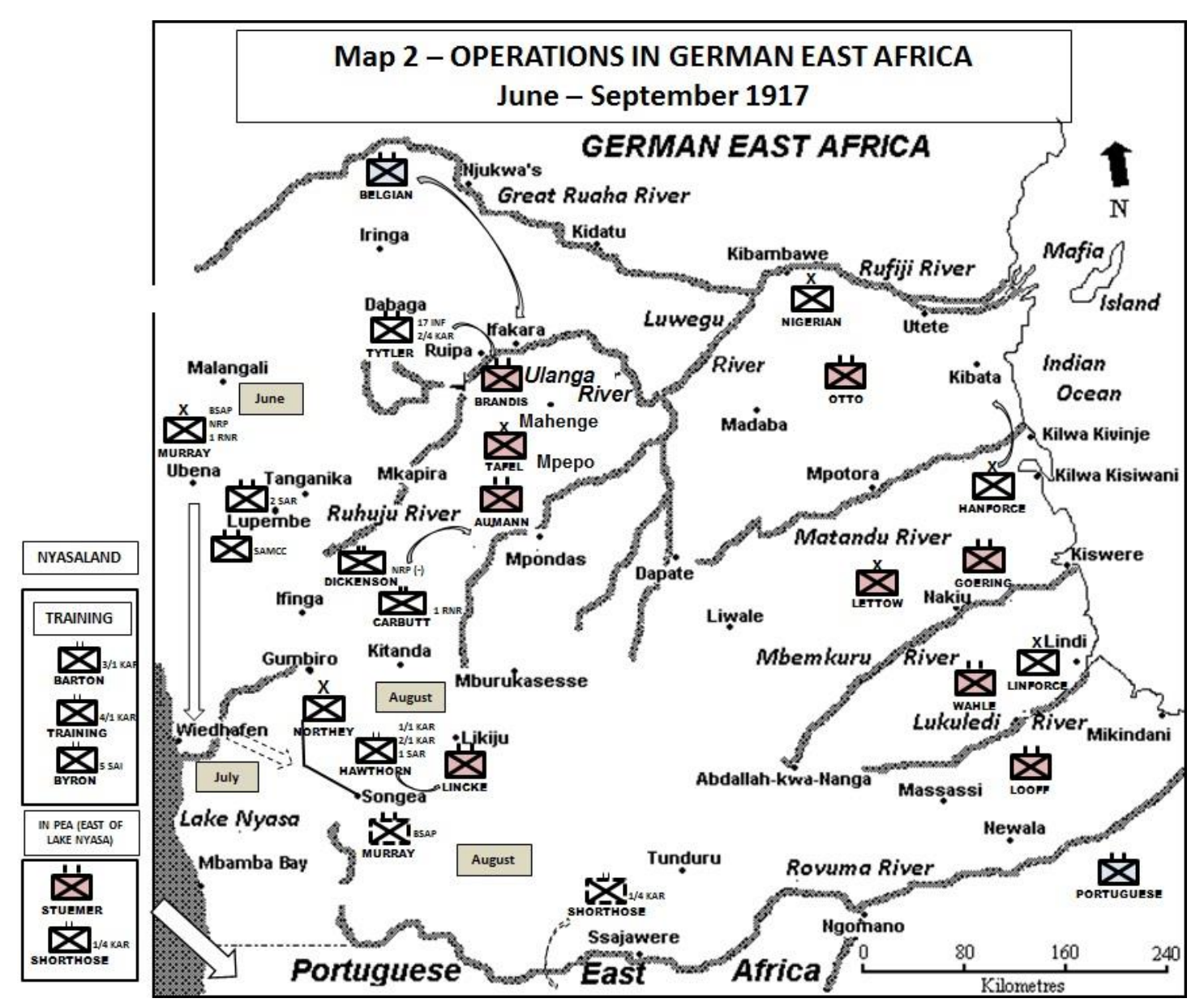

Map 2: Operations in German East Africa (June-September 1917)

Norforce used most of June to prepare itself for the arduous moves ahead. Col. Murray's column had completed its epic march, reaching Wiedhafen on 25 June. Murray then moved up to Songea where he assumed command of the reserve force there, reinforced by $1^{\text {st }}$ RNR. Furthermore, with $1^{\text {st }}$ and $2^{\text {nd }}$ SAR almost ineffective due to sickness, Northey disbanded them and converted the remaining personnel into Lewis gunners. They were then distributed amongst the new African battalions to provide additional firepower and experience. With the return of Murray's troops, Norforce was stronger than before, but the advancing columns were hardly overwhelming. The Likuju column under Col. Stevens, based on 2/1 ${ }^{\text {st }} \mathrm{KAR}$, had about 900 rifles, compared to Abt. Lincke's 600, while Carbutt's 650 men of the $1^{\text {st }}$ RNR faced 350 of Abt. Aumann at Mpepo and Shorthose's 700 rifles of $1 / 4^{\text {th }}$ KAR were ranged against the 400 of Abt. von Stuemer. ${ }^{112}$

In the centre, Stevens' preparations were nearly upset by the enemy. Abt. Lincke, with four companies and a battery near Likuju, was unaware of the scale of the British build-up. Ordered to attack the British camp, on 28 June, Lincke launched a strong assault that surprised Stevens. The defenders held their ground and the Germans broke off the attack just in time to escape encirclement from two nearby British columns that were preparing for their own advance. Once the danger was over, Norforce's leading elements converged on Likuju for rest and final preparations. ${ }^{113}$

While these preparations were underway, Tafel, now in command at Mahenge, had major problems to overcome. His troops were necessarily dispersed owing to a lack of food, and the passage of orders was correspondingly slow and cumbersome. He faced a growing threat from the Belgians in the north-west and Norforce in the west. ${ }^{114}$ Despite expecting a fresh offensive, Tafel could not 
concentrate his troops until the last minute and was heavily reliant on the initiative of his detachment commanders who were of variable quality.

Norforce began its advance on 2 July with the aim of locating and destroying Abt. Lincke. It was located the next day, some 23 kilometres from Likuju at the important track junction linking Songea-Liwale and Songea-Mahenge. $1 / 1^{\text {st }}$ KAR was ordered to attack, while the remainder of Murray's Rhodesians finally arrived at Songea after their arduous return march. The enveloping move took a few days to develop as the deep ravines and densely vegetated valleys were difficult to negotiate. Finally, with the encirclement complete on the night of 6/7 July, the Germans hastily evacuated their very strong position, leaving behind a considerable quantity of equipment. Escaping, with a number of casualties, they made good use of darkness and some newly cut bush paths. Lincke himself was evacuated, sick, to Mahenge and command devolved to Capt. Poppe. ${ }^{115}$

The advance continued, although Abt. Poppe moved unexpectedly north rather than towards Liwale as it was short of food, using delaying tactics, so as not to become decisively engaged. Equally, Norforce's leading troops were beginning to outpace the supply columns, as previously ordered motor vehicles had still not arrived. In the meantime, much further south, Shorthose's $1 / 4^{\text {th }}$ KAR was closing in on Mwembe, some 240 kilometres north-west of Fort Johnston, preparing to attack Abt. von Stuemer there. After ambushing a German patrol on 5 July, the battalion attacked Mwembe the next day and drove out the defenders. ${ }^{116}$

On his northern flank, the small force of about 650 under Col. Carbutt was preparing to move on Mpepo against Abt. Aumann which was estimated to have 350 rifles and five machine guns. This move was intended to draw off any German reinforcements for Mahenge and thereby assist the Belgian advance further north from Iringa. Norforce also made maximum use of the slender air resources available. With one aircraft based at Likuju and another pushed forward to Mwembe, they were constantly engaged in reconnoitring and bombing enemy positions. Supply dumps, usually based in highly flammable grass huts, were a favoured target and several small successes were achieved. With the advance going well, Northey convinced Van Deventer that he should abandon the advance on Liwale in favour of following the enemy to Mpondas, so as to concentrate on destroying the enemy rather than seizing ground. Although the Belgian build-up was going slowly, Northey's request to continue the simultaneous drives against Abt. Aumann in the north and Abt. von Stuemer in the south were approved. ${ }^{117}$

By the middle of the month, Norforce was fully engaged in all three areas, pushing back the various enemy detachments. On 15 July, the welcome news of the arrival of the first Belgian contingent at Iringa was received, although tempered ten days later by learning that the Belgians would not take over the Lupembe-Mpepo sector as previously agreed. As recompense, Van Deventer promised to send $2 / 4^{\text {th }}$ KAR from Iringa to Northey although this was little comfort to the thinly stretched Norforce. Further to the north. the column of NRP and $1^{\text {st }}$ RNR, now commanded by Lt Col. Fair, had forced back Abt. Aumann between Mpepo and Mkapira on the right bank of the River Ruhudje by 26 July, but lacked the strength for an all-out attack. ${ }^{118}$

At the beginning of August, Gen. Northey remained highly concerned about the dispersion of his force which, despite having nearly 4000 effectives, was split into five columns over a front of 480 kilometres. This, and the need to cover Mpepo, meant that he was unable to concentrate on Tunduru in the south. In the north, Fair's troops had invested Abt. Aumann at Mpepo, followed by heavy, but indecisive fighting. The main column under Stevens had advanced steadily and fought a number of minor, but time-consuming, rearguard actions to bring it within five kilometres from Mpondas, where Abt. Lincke was heavily fortified. More positively, Shorthose's column was making excellent progress 
against Abt. von Stuemer. ${ }^{119}$ Van Deventer advised caution, and wanted Northey to hold Shorthose on the Rovuma River; Northey disagreed, noting:

The Chief's orders to me are to deny the rich TUNDURU district to the enemy, this can only be done by driving the enemy out of it and occupying it ourselves; if we are to take no risks we shall never finish this campaign. Chief telegraphs agreeing. ${ }^{120}$

Unhappy with events, Northey arranged for a meeting with Sheppard, Van Deventer's Chief of General Staff (CGS), on 16 August in order to discuss future plans face to face. There, they resolved a number of issues and agreed that a rapid advance by Hanforce and Linforce from the east would be necessary to end the campaign. In the meantime, the resolution of the crisis in Nyasaland enabled Col. Hawthorn to assume command of the column opposite Lincke. Elsewhere, the tactical situation was improving, as Shorthose had cleared almost 400 kilometres of Portuguese territory, having outmanoeuvred his opponent, crossing the rapidly flowing and crocodile-infested Rovuma without boats by improvising rafts and ropes out of tree bark and grass. Finally, Northey held Murray's column in reserve, securing the lines of communication, as he could not supply them moving Tunduru. He also retained three battalions in Nyasaland partly for security, but mainly to continue their training, which was still not highly advanced. Norforce continued to construct motor roads, of which a total of 2400 kilometres were ultimately constructed as a means of ensuring logistical support and also local tactical mobility. ${ }^{121}$

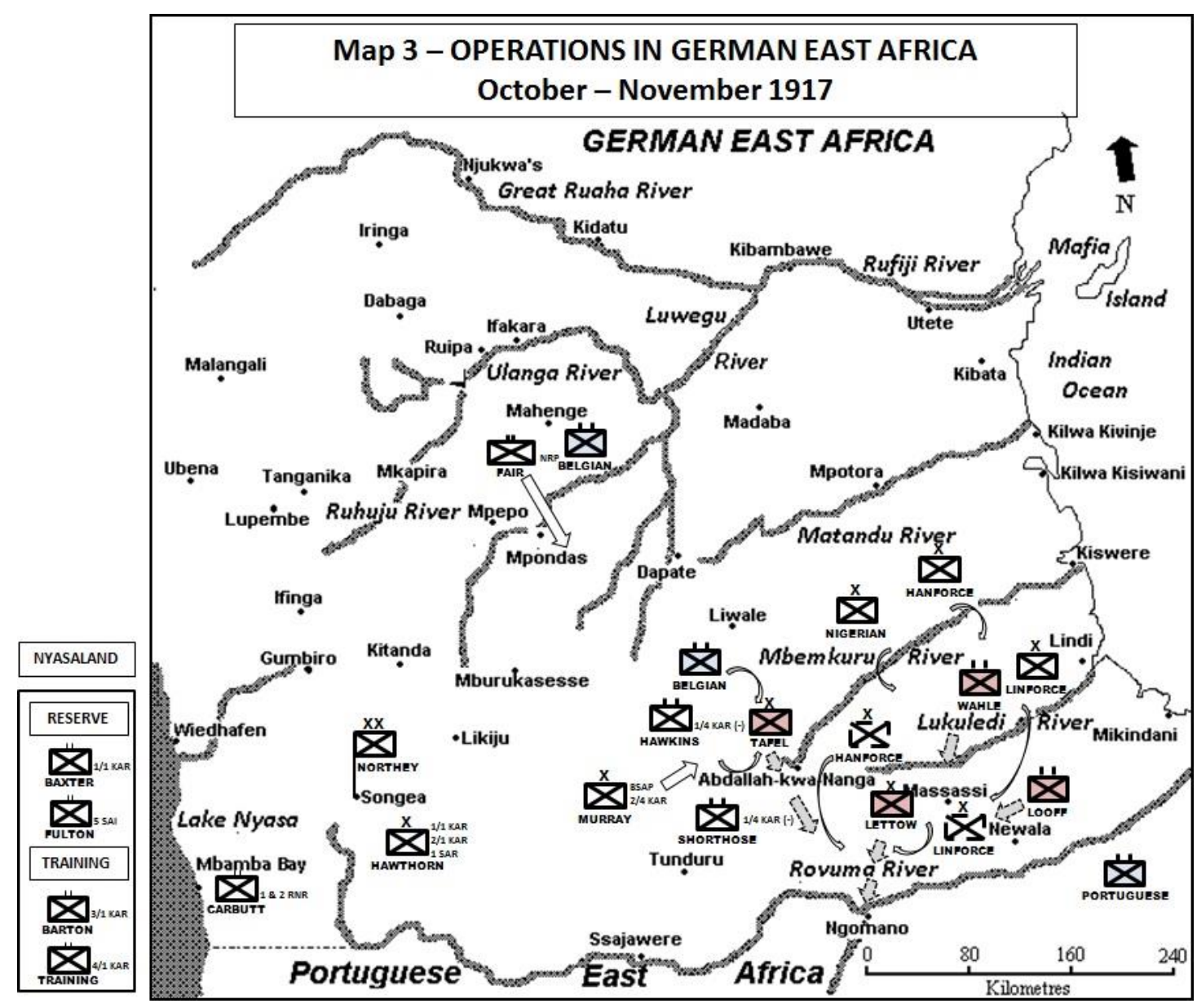

Map 3: Operations in German East Africa (October-November 1917) 
Both Lincke and Aumann launched counter-attacks at Mpondas and Mpepo respectively on 22 August. They were easily held off, but it was apparent that the stubborn resistance there was being used to cover the withdrawal of the forces north of Mahenge. Northey was now instructed to attack both places until they had fallen, while also denying the enemy the Tunduru district and preventing any attempted re-entry into Portuguese East Africa. Shorthose duly took Tunduru in a daring move the next day while Fair continued to tighten the encirclement at Mpepo. Aumann decided to evacuate during the night of 27/28 August, but a hot pursuit followed in which the Germans suffered heavily, with nearly a third of their force as casualties. By the end of the month, Norforce had inflicted significant losses on the Westtruppen, with 22 Germans and 241 Askaris being confirmed casualties and three guns taken. ${ }^{122}$ August had brought success at relatively low cost.

With a resumption of the general advance planned for the third week in September, Norforce continued its pressure on the Germans with the advance continuing slowly in the difficult and broken terrain. Hawthorn forced Otto, who had replaced Lincke out of Mpondas, while Fair maintained his pursuit of Abt. Aumann. ${ }^{123}$ Aerial reconnaissance and bombing were used to good effect, and caused some disruption to the supply system of the enemy. The Belgian advance on Mahenge was now telling and Northey drove his troops as fast as they could manage. Throughout the month, the Germans launched a number of sharp counter-attacks against the various columns, but all were driven off without difficulty or heavy loss. Despite the apparent superiority of the situation, Northey was aware of the real problems:

It will be our utmost endeavour to prevent them - but the distances are so great, the country so hilly and broken, and so full of deep ravines and dense jungle, that it is next to impossible to stop their escape if they choose to avoid fighting. ${ }^{124}$

With the Belgians closing on Mahenge from the north and east, Fair was some 40 kilometres south-west and Hawthorn 80 kilometres south of that place, the ring was closing on Tafel who still had more than 1500 rifles available. Murray remained in reserve, securing Hawthorn's communications, while Shorthose held Tunduru with a further four new KAR battalions training in the rear areas. As ever, supply remained critical with all of the forward columns at their maximum limit of radius, namely 400 to 480 kilometres by road from Lake Nyasa and 1370 kilometres from the sea base at Chinde. Now employing more than 6000 soldiers and 30000 African carriers, Northey remained acutely conscious of his administrative responsibilities and limitations. ${ }^{125}$

As his fighting troops pushed on, the SA Engineers were hard at work improving the road network. They had cut a motor road from Wiedhafen to as far as Likuju and were in the process of extending it to Mpondas. This was important as it was now clear that Tafel was withdrawing from Mahenge and heading south-eastwards towards Liwale. ${ }^{126}$ Abt. Otto was critical to this move and held on determinedly against Hawthorn's best efforts. The country was some of the worst experienced in the campaign and ideally suited to defensive operations. Then Van Deventer changed his priorities, ordering Northey to reinforce Hawthorn in an attempt to clear the Mahenge area of the enemy. This meant a further delay and it was not until 19 October that the attack was ready, by which time Otto had withdrawn. For his part, Fair continued the pressure on Abt. Aumann, causing small but steady losses, while Shorthose pushed a detachment under Maj. Hawkins towards Abdallah-kwa-Nanga east of Liwale. ${ }^{127}$

Van Deventer now hoped that Norforce would be able to cut off any escape by Tafel. By now, this was an optimistic assumption and undermined by the problems of extended supply lines of another 80 kilometres. This was made more difficult by the decision to withdraw all the Belgians back to the Central Railway before the coming rainy season - it would mean more ground for Norforce to cover. $^{128}$ 
November began with promise as Hawthorn's attack managed to catch Otto off-guard and Hawthorn took 24 prisoners and a machine gun near Luwegu. Hawkins's detachment linked up with a Belgian battalion at Liwale, while Murray began to patrol along the Songea-Liwale road. ${ }^{29}$ By the middle of the month, it was obvious that Tafel was in the process of moving south. While Northey was ready, he was hampered by the fact that the enemy were moving along an arc at the limit of his supply reach. He simply could not feed his troops beyond this line, and both Fair and Hawthorn had lost touch with the enemy. Murray was ordered to Abdallah-kwa-Nanga in an attempt to cut off Tafel, but the latter had a head start. ${ }^{130}$

The race was on and Tafel arrived first, heading the half battalion at Abdallah- kwa-Nanga with about 10 companies. Hawkins's men of $1 / 4^{\text {th }}$ KAR fought gallantly and were supported by a Belgian column from Liwale and then Shorthose himself. Heavily outnumbered, the detachment had inflicted many casualties on the attackers and had disrupted their move south. Most important was the seizure of a copy of Tafel's orders for the move south. This was invaluable information that was quickly sent to Van Deventer. With the chance of cutting the Schutztruppe in half, Northey instructed Murray to attack any enemy within range of Tunduru while Hawthorn was moved back to Songea, in reserve, and to be ready to return to Nyasaland if necessary. The NRP were instructed to take over Mahenge from the Belgians and provide the occupying force there. ${ }^{131}$ Much needed reinforcements in the form of $2^{\text {nd }}$ RNR, some 500 strong, joined $1^{\text {st }}$ RNR at Mbamba Bay for training and operations. ${ }^{132}$

Norforce spent the remainder of the month redeploying its columns and patrolling vigorously. With Tafel out of range, it could do little more than to remain poised to strike at any enemy detachments that came within reach. However, with Lettow's capture of Ngomano, on the Rovuma River, and advance into Portuguese East Africa, a move back to Nyasaland appeared highly likely. Fortunately, Van Deventer's forces managed to trap Tafel near the border where he surrendered on 27 November. ${ }^{133}$ The Schutztruppe had been cut in half, but still remained dangerous.

\section{The drive into Portuguese East Africa: December 1917-May 1918}

The month of December was spent largely in reorganisation as the heavy rain put paid to further operations. Northey paused to reflect on the military situation, noting that his main column under Hawthorn was at the limit of its supply near Likopolwe while Murray's Rhodesian/KAR column stationed on the Wiedhafen-Songea-Tunduru line saw no sign of the enemy. ${ }^{134}$ Northey resolved to continue pushing Hawthorn as far east towards Luambala as possible, subject to the difficult supply situation and the continuing rain. ${ }^{135}$ There were other important considerations too: his experienced KAR battalions were worn out after several years in the field, $2 / 4^{\text {th }}$ KAR had to be pulled back to receive more than 400 reinforcements, while its sister battalion, $1 / 4^{\text {th }}$ KAR was equally in need of a rest. ${ }^{136}$

With the flooding of the Rovuma River and a lack of a developed sea base in Portuguese East Africa, the main body under Van Deventer was largely forced to halt and consolidate. Norforce now became the principal striking arm, although it too had to contend with the tropical monsoon. With the difficult conditions, the best that Northey could do was to push a limited force north-eastwards from Nyasaland while a two battalion-sized column, known as Rosecol, moved westwards from Porto Amelia under the newly established Pamforce. Col. Hawthorn was chosen to lead the move with $1 / 1^{\text {st }}$ and $2 / 1^{\text {st }}$ KAR ranged against the eight companies of Abt. Wahle and Kraut around Luambala. To ease his supply problems, Northey also sought, unsuccessfully, to hand over responsibility of the SongeaTunduru area and concentrate his troops in Nyasaland. For the time being, his troops remained spread out in two major groupings, some hundreds of kilometres apart. On a personal note, on 1 January 
1918, Northey's services were recognised by promotion to Major General for "distinguished services in the field". ${ }^{137}$

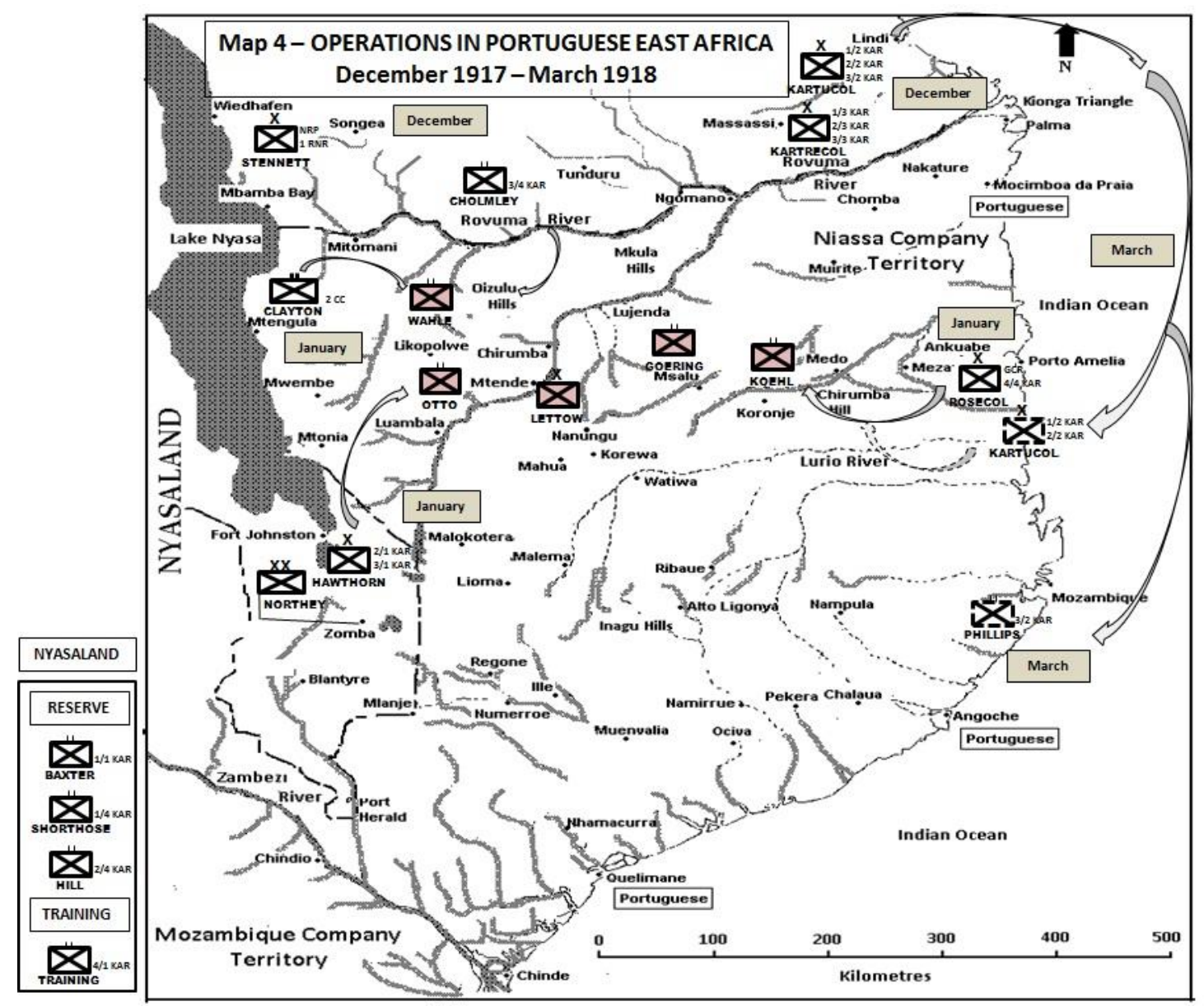

Map 4: Operations in Portuguese East Africa (December 1917-March 1918)

Hawthorn marched north on 3 January to dislodge Abt. Wahle from its food gathering mission around the River Lugenda. His two battalions threatened the Germans, and Lettow despatched reinforcements in the form of Abt. Otto from Chirumba, while the $2^{\text {nd }}$ Cape Corps moved on Mwembe. ${ }^{138}$ However, Hawthorn was determined and, despite the swollen rivers, he was able to outmanoeuvre Wahle from a strong position. The latter withdrew eastwards before Otto could arrive and the British were able to occupy Likopolwe and then Luambala by 18 January. The immediate goal was achieved, but Hawthorn could not advance further owing to a lack of carriers and the deteriorating road conditions. ${ }^{139}$ Elsewhere, $1 / 4^{\text {th }}$ and $2 / 4^{\text {th }}$ KAR were brought down by steamer to Fort Johnston to rest and prepare for future operations. ${ }^{140}$

Hawthorn's advance had deprived Lettow of an important food-growing area and influenced his decision to concentrate further east in the Nanungu area. With supplies becoming short for the Germans, the British advance was both unexpected and disconcerting. ${ }^{141}$ In the east, Rosecol was now operating some 80 kilometres west of Porto Amelia, but was too small to dislodge the enemy. Lettow needed time for the new crops to ripen and he ordered Abt. Otto to stop Norforce's more dangerous incursions. ${ }^{142}$ 
Using the period of reduced operational activity, Northey inspected his lines of communication back in Nyasaland. Uncharacteristically, he found matters to be unsatisfactory and he summarily replaced the officer in charge with an experienced businessman turned soldier. Matters were soon sorted out and the rear areas returned to their accustomed efficiency. Other problems included the loss of a number of his experienced Southern Rhodesian troops as their engagements had expired. The two RNR battalions now merged into one unit more than 1000 strong bearing the $1^{\text {st }}$ RNR title, but the new troops were inexperienced and needed further training. A major blow was the loss of Col. Murray who was invalided out with a heart problem. Even though he was not always popular with his officers owing to his hard-driving ways, he had been one of the best and most reliable column commanders over the previous two years and would be missed. Indeed, Northey later described him as "one of the finest soldiers I have ever come across". Col. Carbutt, formerly of the RNR, took over his appointment. ${ }^{143}$

In early February, Northey was summoned to a conference with General Van Deventer in Beira, Portuguese East Africa. There they discussed the best means of ending the campaign while tackling the thorny issue of how to employ their Portuguese allies with the least danger. ${ }^{144}$ Northey advocated his own method, that of incorporating small detachments within his own columns. The Cin-C also outlined his plans for 1918 with the aim of driving the Germans south of the Porto AmeliaMtengule line. Northey noted that this still gave the enemy plenty of room for manoeuvre:

I said I should do all possible to carry out this plan: in fact I have nearly done my share of it already. But it is 400 miles [650 kilometres] across from the Indian Ocean to Lake Nyasa, and the extent of country is enormous, so that one cannot guarantee that in establishing the proposed line, one can keep the enemy south of it. ${ }^{145}$

Northey realised that conditions were far from ideal as the Germans maintained their usual tactics of delay while his own supply lines were stretched to the maximum, the heaviest rains were falling and sickness was rife. Nevertheless, his troops remained in good heart and continued to fight hard, causing the enemy a constant stream of casualties. ${ }^{146}$ But even he had to bow to the inevitable and ordered a pause in which to bring up supplies to the areas of Luambala and Mtarika in order to supply the forward troops on the Lujenda. This still meant keeping as large a striking force as possible forward, but under the circumstances it could be little more than a battalion. Hawthorn's experienced troops were suffering too, and $1 / 1^{\text {st }}$ KAR was withdrawn into reserve, having served for over three and a half years in the field. $2 / 1^{\text {st }}$ KAR was in similar condition, but had to continue for the time being. ${ }^{147}$

Despite the appalling conditions, Hawthorn continued to press as far east as his supply lines would allow him. On 22 February, Hawthorn, now some 240 kilometres from his base and some 120 kilometres east of Luambala, hit Wahle and Kraut hard. Unfortunately, on the coast, Rosecol was stalled for lack of transport and could not exploit the success. ${ }^{148}$ But, the combination of British pressure and German supply difficulties lead to the increased concentration of the Schutztruppe around Nanungu. ${ }^{149}$ As this shift took place, Northey was preparing for the next phase of his effort and shifted troops east and south of Fort Johnston towards Malokotera and Regone-Inagu. These were intended to deny the areas to Lettow's foragers while detecting any moves to the south. He realised the futility of trying to anticipate Lettow's movements and instead kept his two resting KAR battalions in readiness to move towards the Zambezi River. As ever, he considered the best defence of his lines of communication an aggressive posture some 160 kilometres inland although he remained rightly disappointed with the progress of Rosecol. ${ }^{150}$

The latter force continued to move slowly inland during March while Norforce spent much of the time collecting supplies and the carriers to move them forward. The next objective was Msalu in 
coordination with Pamforce from Medo. Despite these efforts, the most that Northey could supply were three columns of about 300 rifles each, operating from Mtarika, Luambala and Namweras. These troops would move to their extreme limit of supply while constantly seeking to hit the Germans. ${ }^{151}$

March continued to experience the heavy rains that seriously impeded the planned movements and made the crossing of rivers difficult. At the end of the month, reports were received that Germans intended to break north and evade the planned British squeeze. Northey accordingly resolved to move early and not to await the start of Pamforce's own move. He saw his mission as preventing the enemy from breaking either west or north while Pamforce pushed towards Nanungu. ${ }^{152}$

By the middle of April, with his forward columns still pressing on in the sodden conditions, Northey had to face another intractable problem - the lack of carriers. He needed an extra 5000 carriers just to get forward of Mtarika-Mahua and these carriers were simply not forthcoming. The crops were not due to ripen until May at the earliest and this constrained his options. Still, he resolved to keep up the pressure despite the risks to his relatively small forward detachments. ${ }^{153}$

It took 11 days to traverse his lines of communication from front to rear with only a single platoon available for its protection. More defenders would have simply consumed the rations needed for the front. ${ }^{154}$ By 26 April, Pamforce was closing in on Lettow's main body around Nanungu while $3 / 1^{\text {st }}$ KAR under Col. Barton moved on to support from the west. Several days later, a German raid on those vulnerable lines of communication disrupted preparations, but prompt action restored the situation. On 4 May, $3 / 1^{\text {st }}$ KAR was ready to strike Nanungu.

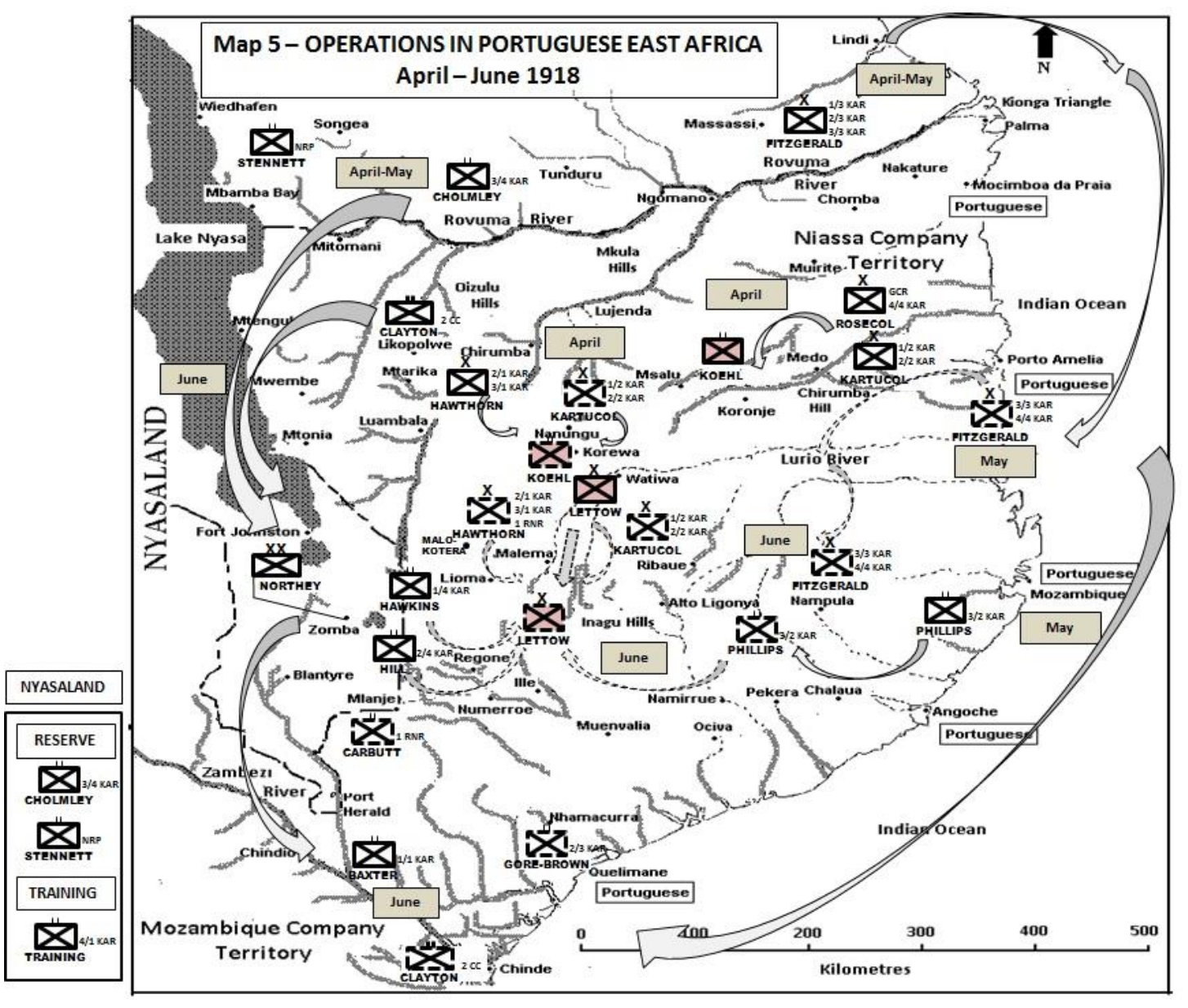

Map 5: Operations in Portuguese East Africa (April-June 1918) 
It was to be a savage fight as the battalion initially surprised the Germans, before a heavy counter attack. The fighting went on until nightfall, with numerous casualties, but by daybreak, the KAR were in possession of the field and the enemy had withdrawn. The action cost $3 / 1^{\text {st }}$ KAR more than 100 casualties, but it had given the enemy a similar number, losses that could be ill afforded by the Germans. ${ }^{155}$

Owing to the length of Norforce's supply lines, much of the fight fell to Pamforce, with $3 / 1^{\text {st }}$ KAR, now under Col. Griffiths, taken under the former's command and continuing the pursuit. On 22 May, the battalion ran into the enemy rear guard near Korewa, south of Nanungu. It was heavily counter-attacked, but held on while the remainder of the column came into battle. Once again, it was a bloody success with the capture of a large number of enemy soldiers, carriers and equipment. Elsewhere, Northey had sent out a number of patrols to deny the enemy food and to act as an early warning. ${ }^{156}$

At the end of May, as the Schutztruppe moved south, Northey regrouped his forces with the main striking elements of four battalions under Hawthorn $\left(2 / 1^{\text {st }}, 3 / 1^{\text {st }}\right.$ and $1 / 4^{\text {th }}$ KAR with NRP) while he retained direct control of $2 / 4^{\text {th }} \mathrm{KAR}$ at Mulanje-Regone, $2^{\text {nd }}$ Cape Corps securing Mwembe, plus $3 / 4^{\text {th }}$ KAR guarding Songea-Tunduru and two others in reserve $\left(1 / 1^{\text {st }}\right.$ and $\left.2 / 1^{\text {st }} \mathrm{KAR}\right) .{ }^{157} \mathrm{He}$ was now ready to hit them as soon as they came into range. By early June, the German-led elements were approaching lightly held Malema, which was evacuated after a stout defence. With troops of both sides approaching from all directions, Northey thought it time to give the column commanders more freedom to act:

It appears to me that the Campaign seems now to have reached a stage when elaborate plans for cooperation worked out on a map are useless and only cause delay ... Each to act on initiative of its own commander who should have orders to take up offensive vigorously against any enemy within reach, without waiting for each other or their superior's orders. The main thing is to regain the initiative and give enemy no respite. ${ }^{158}$

In a major converging movement, Pamforce continued to drive south and east towards Malema with $1 / 4^{\text {th }}$ KAR pressing in from the west and $2 / 4^{\text {th }}$ KAR from the south. By 15 June, $1 / 4^{\text {th }}$ KAR had reached Malema while $3 / 1^{\text {st }}$ KAR continued to pursue the enemy. Northey also began to reinforce other posts around the area with the aim of disrupting any advance, but the bulk of fighting units came under Pamforce's command. This unaccustomed inactivity however also marked the end of Gen. Northey's tenure as he had been selected as the next governor of the East Africa Protectorate, later to be renamed Kenya Colony. He handed over command to Brig. Gen. Hawthorn, and departed for Chinde on 28 June 1918. While much hard marching and several severe fights remained before the war ended in November, Northey had had a successful tenure in command. ${ }^{159}$ His valuable services were recognised with the king presenting him the Companion of the Order of the Bath (CB) in September and then a knighthood in the grade of a Knight Commander of the Most Distinguished Order of Saint Michael and Saint George (KCMG) in December 1918. ${ }^{160}$

\section{Conclusions}

In assessing Brig. Gen. Northey's two and half years in command of Norforce, his achievements must be measured against the challenges of his environment and his opponent. In a campaign that was marked by hardship and extreme difficulties for all participants, Norforce was particularly challenged by the tyranny of distance and terrain. Essentially a large infantry brigade, it had to operate its own base and sustain itself successfully over 2600 kilometres in the rear area just to reach the northern borders of Nyasaland and Northern Rhodesia. From there, Norforce HQ had to maintain the fighting 
troops several hundred kilometres into the forward zone often with two or three main columns separated by 200 to 320 kilometres of dense bush and mountains. The extremes of climate ranged from the cold and wet mountain highlands between Mwaya and Iringa to the hot and steamy floodplains of the Ulanga basin. Tropical diseases and voracious insects made life very unpleasant for all.

In the Schutztruppe, Northey faced a professional and well-trained force that was highly proficient in bush warfare. Once its fixed bases had been lost in 1916, it kept on the move, albeit mainly constrained by the need to seek new sources of food. Frequently trying to trade space for time, Lettow never lost his penchant for attacking and destroying any isolated or small detachments found in his way. In the attack, the Germans made excellent use of machine guns, conducting outflanking movements through the bush to envelop a position. When on the defence, the Schutztruppe was skilled at constructing strong positions that would be held tenaciously with sudden and fierce counterattacks to restore any losses. Then, before being surrounded, it would slip away into the bush at the last minute. It would remain a dangerous, if much diminished, foe right up until the end of the campaign in 1918.

Isolated from the relative abundance of manpower, equipment and material provided to the main British force in the north, Norforce was always the poor relation of the theatre. But Northey took this as a professional challenge and met it ably. He showed particular ability in the management of his lines of communication while using the good relations established with colonial governments to ensure the regular production of food and steady recruitment of carriers. He grasped the importance of mobility as he continually sought to extend his road network so that the MT could move supplies as far forward as possible before the carriers had to take over. This was complemented by excellent and innovative use of his motor vehicles, both tactically and logistically. Furthermore, he employed the small squadron of steamers on Lake Nyasa to very good effect to support the campaign in the southern area as well as in Portuguese East Africa.

While his troops certainly experienced their fair share of hunger and privation, shortages were usually temporary and were overcome by adjustments to the lines of communication. Medically, Norforce also suffered heavily from disease and the climate, but still managed to maintain its mobility and fighting effectiveness even during the wet seasons. This was in stark contrast with the virtual collapse of the main force in the north during late 1916 to early 1917 . Whatever the difficulties, Northey's troops never lost faith in their commander's ability and determination to do the best for them.

As a thinking professional soldier, he used his previous experiences on the Western Front, especially the effects of modern weapons, to good effect, and instilled the same into his subordinates. He adapted well to the African environment, recognising that detached columns, controlled by wireless, were essential to success. He also understood the need to inflict attrition on the Schutztruppe and to deny it access to food.

Northey appreciated the importance of supporting the main force in the north and often took risks in doing so, but tempered these by thorough and meticulous planning beforehand. He was overextended at Iringa in November 1916 and was seriously threatened with defeat by Wahle from the west and Kraut from the east. But he managed to out-manoeuvre Kraut while holding enough ground against Wahle, so that the threat soon passed. Northey was able to regain his balance and used this tactical mobility to isolate and then capture several important enemy groups.

The breakout of Wintgens in 1917 tested Northey's ability to manage two isolated forces separated by huge distances. Despite the former's head start, Murray's column hounded Wintgens for much of the way and, if Murray was unable to destroy the raiders, it was still an extraordinary effort. 
Likewise, operations in the southern area in mid- and late-1917 took much determination and effort before clearing the enemy out of the Mpepo and Mahenge areas. These were characteristic of Northey's operations: bold advances with widely separated columns that were backed by careful and methodical administrative planning.

Norforce was instrumental in assisting the capture of Tafel's force in late 1917 and then became the primary striking force in Portuguese East Africa in early 1918. By that stage, column commanders were given greater freedom to chase the elusive Schutztruppe and the whole focus of support had to be shifted southwards. Northey's troops would continue their offensive operations until the end of his command. He was certainly aided by the high quality of his column commanders, especially Murray and Hawthorn. These were hard-driving, tough and reliable officers who could be entrusted to overcome enormous difficulties. But, their selection also reflected Northey's skill in choosing subordinates, as those he deemed to be unequal to the task were quickly removed. This was an important factor in running such a mixed and varied force spread over such vast areas.

Northey's personal qualities played an important role in his success. He was certainly a determined, tough and daring commander who commanded considerable respect. Although a realist, he maintained cheerful optimism in the face of tremendous physical adversary and apparently impossible challenges. He tempered risk-taking with careful and thorough planning. Consequently, he was able to react to the unexpected in a timely and effective fashion. He had the important ability to get on well with 'colonials' and units from completely different backgrounds.

He also presided over a notable expansion of his locally raised forces between 1917 and 1918 with the growth of the $1^{\text {st }} \mathrm{KAR}$ and the $1^{\text {st }} \mathrm{RNR}$. Together with the raw $5^{\text {th }} \mathrm{SAI}$, these troops were trained in Nyasaland before being launched into the fighting line with varying degrees of success. If not as experienced as their worn-out predecessors, they learned on the battlefield and were invaluable in harrying the Schutztruppe incessantly.

To evaluate Northey's performance: he clearly fulfilled his main mission of securing northern Nyasaland and Northern Rhodesia from the enemy. Thereafter, he remained tactically agile and supported the advance of the main British force with considerable vigour. He showed aggression and determination in pushing the enemy hard. Operationally he was successful in clearing much of the southern part of German East Africa throughout 1916 and 1917, and subsequently Portuguese East Africa during 1917 and 1918. While he was unable to inflict a knockout blow on the Schutztruppe, he hit them hard on a number of occasions while avoiding any serious defeats for his force. He kept up the pressure throughout and helped to reduce the enemy to a rump force by mid-1918.

Norforce achieved a great deal with very slender resources and little fanfare in one of the most difficult environments of the war. This success may be attributed to Northey's professional skill and leadership, as well as a force of highly determined and capable troops. Handing over command before the end of the war and always a modest man, Edward Northey never achieved the wider public acclaim which was his due. But, based on his consistently successful and aggressive performance, he must be considered the outstanding British commander of the East African campaign. Both he and Norforce deserve full credit for their remarkable military achievements.

1 This paper was originally presented to the War \& Society Conference at the South African Military Academy, Stellenbosch University, in June 2003. I am grateful to Professor Ian van der Waag for his subsequent critique and insightful comments on the paper as well as the anonymous referees.

2 In the past decade, increased interest in the East Africa Campaign has been reflected in a number of important studies: Hew Strachan's magisterial The First World War Volume I: To arms. Oxford: Oxford University Press, 2001 covers the conflict in considerable detail and places it within the global strategic context. Full-length studies include R Anderson. The forgotten front: The East African 
Campaign 1914-1918. Stroud: Tempus, 2004; E Paice. Tip and run. London: Weidenfeld \& Nicolson, 2007; A Samson. Britain, South Africa and the East Africa Campaign 1914-1918. London: IB Taurus, 2005; A Samson, World War I in Africa: The forgotten conflict among the European powers. London: IB Tauris, 2013; and T Stapleton. No insignificant part: The Rhodesian Native Regiment and the East African Campaign of the First World War. Waterloo: Wilfrid Laurier Press, 2006. The latter part of the conflict is covered in more detail in R Anderson. "World War I in East Africa 1916-1918". Unpublished PhD thesis, University of Glasgow, Glasgow, 2001. <http://theses.gla.ac.uk/5195/>. For the Portuguese side, see R Pélissier. Naissance de Mozambique, 2 vols. Montamets: Editions Pélissier, 1984 and Les Campagnes Coloniales du Portugal 1844-1941. Paris: Pygmalion, 2004; the Belgians are covered in Royaume de Belgique Campagnes colonials belges, 3 vols. Imprimerie Typographique de l'I.C.M., 1927-1932. For the German side, the rare, but indispensable, work by L Boell. Die Operationen in Ostafrika. Hamburg: Walter Dachert, 1951 covers the campaign in considerable detail. The most famous name of the East African Campaign was the German Commander of the Schutztruppe, Lieutenant Colonel and subsequently Brigadier General Paul von Lettow-Vorbeck. His most famous work is Meine Erinnerungen aus Ostafrika. Leipzig: Hase \& Köhler, 1920, which he published in an English version as My reminiscences of East Africa. London: Hurst and Blackett, 1920, reprinted Nashville, TN: The Battery Press, n.d. His wider life story that included East Africa was published by his daughter, Ursula von Lettow-Vorbeck, as PE von Lettow-Vorbeck. Mein Leben. Biberach an der Riss: Koehlers, 1957. This rare volume has been supplemented by a useful recent English translation: General Paul von Lettow-Vorbeck. My life. J Pierce \& R Dohenrend (trans.). Love Park, IL: Rilling Enterprises, 2012. A modern biography by E Michels. Der Held von DeutscheOstafrika Paul von Lettow Vorbeck: Ein preußischer Kolonialoffizier. Paderborn: Ferdinand Schöningh, 2008 examines Lettow's personality and outlook in considerable detail. Officially, British East Africa (modern Kenya), Uganda and Zanzibar fell under the East African desk at the Colonial Office, while Northern Rhodesia and Nyasaland came under the South African grouping. Owing to the nature of the campaign, they will all be considered part of East Africa. H Moyse-Bartlett. The King's African Rifles: A study in the military history of East and Central Africa, 1890-1945. Aldershot: Gale and Polden, 1956, pp. 265-266. Campagnes coloniales belges, I, p. 27; H Schnee, Deutsch-Ostafrika im Weltkrieg, Leipzig: Quelle und Meyer, 1919, pp. 115-116.

R Anderson. The battle for Tanga 1914. Stroud: Tempus, 2002 and Anderson, The forgotten front ... op. cit., pp. 51-57. Great War: Military Operations: East Africa, 1914-1916, Vol 1, London: HMSO, 1941, pp. 171-174. Boell op. cit., pp. 64-65; Hordern op. cit., pp. 176-178.

10 The National Archives (TNA), Kew, Richmond, Surrey, UK, FO 371/1882/50887, Telegram Buxton to Harcourt, 17 September 1914; DO 119/902, Letter Commandant General (Col Edwards) to Buxton, 3 May 1915. The files from the War Office (WO), Colonial Office (CO), Cabinet Office (CAB), Dominions Office (DO) and Foreign Office (FO) are all found at TNA. I am most grateful for the Controller of Her Majesty's Stationery Office for the quotation of Crown copyright material; the Trustees of the Imperial War Museum, the British Library and Weston Library, Bodleian Libraries (WL-BL), University of Oxford; the Bundesarchiv-Militärarchiv, Freiburg; and the South African National Defence Force, Pretoria, for the consultation and citing of material in their care. FO 371/1883/39795, 21 August 1914, Letter FO to CO; FO 371/1883/41836, 22 August 1914, Minute sheet.

Hordern op. cit., pp. 559-561; see E Yorke. Northern Rhodesia and the First World War: Forgotten colonial crisis. Houndsmills: Palgrave Macmillan, 2015 for details of the conflict in Northern Rhodesia.

FO 371/2235/53065, 1 May 1915, Letter Admiralty to FO.

FO 371/2231/115194, 19 August 1915, Telegram Buxton to Bonar Law, 10 August 1915; Telegram Buxton to Bonar Law, 13 August 1915; E Yorke. "War, mobilisation and colonial crisis in Northern Rhodesia, 1914-1916”. British Journal for Military History 2/2. February 2016, pp. 131-136.

Anderson, The forgotten front, op. cit., pp. 101-106.

FO 371/2232/149353, 13 October 1915, Telegram Buxton to Bonar Law, 9 October 1915.

FO 371/2232/149353, Letter CO to WO, 12 October 1915.

Hordern op. cit., pp. 189-190. He notes that Northey was appointed on 13 November 1915; FO 371/2231/181234, Letter WO to FO, 29 November 1915.

Northey left few private papers, mainly copies of war diaries and press cuttings; these are held in the Imperial War Museum (IWM), under Documents 9796 (henceforth Northey papers). However, his 
orders, instructions and telegrams are contained in the WO 95/5229-5330 series of the Nyasaland and North-Eastern Rhodesia Frontier Force (Norforce) War Diaries (WD). I am also grateful to the Royal Green Jackets Museum for providing an obituary of Northey as well as extracts from the regimental journal.

War Office. Quarterly Army List, Quarter Ending 30 June 1914. London: HMSO, 1914, p. 249; "Northey, Maj.-Gen. Sir Edward". In Who was who. London: A \& C Black, 1920-2014. Who was who online edition. Oxford: Oxford University Press, 2014. <http://www.ukwhoswho.com/view/article/oupww/whowaswho/U241342> Accessed on 28 June 2014. WO 95/1358, $1^{\text {st }}$ KRRC War Diary (WD), 27 September and 29 October 1914; War Office. Quarterly Army List, Quarter Ending 31 March 1915, Part 1. London: HMSO, 1915, p. 132. WO 95/1566, 15 ${ }^{\text {th }}$ Infantry Brigade WD, 19 June 1915.

Ibid.

IWM, Northey papers, Undated lecture notes; Hordern op. cit., pp. 187-190. Cites WO letter to CO, 22 November 1915. Repeated in WO 33/858/846, Telegram 13744, Robertson to Smuts, 25 February 1916.

Royal Green Jackets Museum. The King's Royal Rifle Corps chronicle 1954, "Obituary of Major General Sir Edward Northey” by Major General Sir Hereward Wake, January 1954, pp. 111-113. WO 33/858/846, Telegram 13744, CIGS to Smuts, 25 February 1916; Anderson, The forgotten front ... op. cit., pp. 104-106.

British Library (BL), Mss Buxton, Dep 9930, Letter Buxton to Bonar Law, 6 January 1916.

IWM, Norforce WD, 4 December 1915 - 16 February 1916; E Northey, "The East African Campaign". Journal of the Royal African Society XVIII/LXX. January 1919, pp. 81-87.

For a more in-depth discussion of Smuts's command style, see R Anderson. "JC Smuts and JL van Deventer: South African Commanders-in-Chief of a British Expeditionary Force". Scientia Militaria 31/3. 2003, pp. 117-141 and The forgotten front, op. cit.

Details on Norforce's logistic system are scattered, but for greater detail on carriers and transport in East Africa, see Anderson, The forgotten front op. cit.; GWT Hodges. "African manpower statistics for the British forces in East Africa, 1914-1918”. Journal of African History IX/1. 1977, pp. 101-116; G Hodges. The Carrier Corps: Military labour in the East African Campaign. Westport, CT: Greenwood Press, 1986; and D Killingray. "Labour exploitation for military campaigns in British colonial Africa, 1870-1945". Journal of Contemporary History XXIV/3. July 1989, pp. 483-502.

Hordern op. cit., p. 486; RH Beadon. The Royal Army Service Corps: A history of transport and supply in the British Army. Cambridge: Cambridge University Press, 1931, pp. 322-323.

War Office. Field Service Regulations, Part II Organisation and administration. London: HMSO, 1909, reprint 1914, pp. 82-85, 116-117, 122-126; Beadon op. cit., p. 81 and sketch General scheme of supply from the base to the trenches, facing p. 154; T Clarke. Transport and sport in the Great War period. London: Quality Press, 1938; I Brown. British logistics on the Western Front 1914-1919. Westport, CT: Praeger, 1998.

C Baker. The long, long trail: The British Army in the Great War, The Army Service Corps of 1914-1918. <http://www.1914-1918.net/asc.htm\#trains> Accessed on 24 June 2014.

Northey op. cit., pp. 82-83.

IWM, Northey papers, Norforce WD, 19 February - 19 March 1916; 15 April 1916, NF 122, Instructions to commanders, preliminary and supplementary to operation orders, as to the forthcoming advance into German territory, and investment and capture of enemy's bomas (henceforth Instructions).

IWM, Northey papers, Instructions, p. 5.

Northey op. cit., p. 84.

WO 33/858/1002, Telegram NF 182, Northey to Chief of the Imperial General Staff (CIGS), 4 May 1916; WO 95/5329, Norforce WD, Intelligence summary 22 May 1916; Hordern op. cit., pp. 462-463, 485; JG Maker. "A narrative of the Right Section, 5th Mountain Battery, South African mounted riflemen. Central African Imperial Service Contingent, Nyasaland, 1915-1918”. South African Military History Society Military History Journal, Part I, 4/1. June 1977. <http://samilitaryhistory.org/vol041jm.html>, and Part II, 4/2. December 1977. <http://samilitaryhistory.org/vol042jm.html> Accessed on 25 June 2014; HA Cripwell. "Operations around Mpepo, German East Africa 1917”. Rhodesiana 10. July 1964, pp. 54-79. <www.rhodesia.nl/rhodesiana/volume10.pdf> Accessed on 26 June 2014. Cripwell was a veteran of the NRP campaign in German and Portuguese East Africa. Northey only wrote a short article on his experiences immediately after the war: E Northey. "The East African Campaign". Journal of the Royal 
African Society XVIII/LXX. January 1919, pp. 81-87. See also A Clayton. The British Military presence in East and Central Africa. Oxford: Oxford Development Reports Project, 1982.

Hordern op. cit., p. 169.

WO 95/5329, Norforce WD, 23-29 May 1916.

WO 95/5329, Norforce WD, 10 June 1916; Letter Northey to CO, 2 June 1916.

WO 33/858/1047, Telegram NF 360, Northey to CIGS, 29 May 1916; Hordern op. cit., pp. 462-468.

IWM, 2/49538, Kriegstagebuch (KTB), II, Telegram GHQ to Lines of Communication, 17 April 1916. (The four-volume war diaries of Lettow's headquarters were captured and translated at war's end.)

WO 33/858/1062, Telegram F 5227, Smuts to CIGS, 9 June 1916.

WO 95/5329, Norforce WD, 8 and 29 June 1916.

WO 153/111, Map of East Africa; J H V Crowe, General Smuts' Campaign in East Africa, John Murray, 1918.Sketch 4; CAB 45/73, Sketch 74, "The strategic situation, December 1916".

WO 95/5329, Norforce WD, 20 and [30] June 1916; Hordern op. cit., pp. 471-473.

Boell op. cit., pp. 203-204.

WO 95/5329, Norforce WD, 14 July 1916.

WO 95/5329, Norforce WD, 24-25 July 1916.

WO 95/5329, Norforce WD, General situation end July; Stapleton op. cit., pp. 54-55. $1^{\text {st }}$ RNR was raised in Salisbury, Southern Rhodesia, in May 1916, moving to Zomba, Nyasaland, for further training in July and then reaching Neu Langenburg, GEA, in mid to late August 1916.

WO 95/5329, Norforce WD, 1, 3, 5-6, 18-19 August 1916.

WO 95/5329, Norforce WD, 22-31 August 1916; WO 95/5291, GHQ WD, Telegram F5213, Smuts to CIGS, 2 September 1916.

WO 95/5291, GHQ WD, Intelligence report, 3 September 1916.

CO 371/2596/178923, 9 September 1916, Telegram Governor, Nyasaland to CO, 5 September 1916; WO 95/5329, Norforce WD, 20 September 1916; Boell op. cit., pp. 253-254; Stapleton op. cit., pp. 5657.

Hordern op. cit., pp. 504-505 and Sketch 67; WO 95/5229, Norforce WD, "Detailed state of troops as at $30^{\text {th }}$ September 1916"; CAB 44/4, p. 1 and Sketch 67.

WO 95/5329, Norforce WD, 28 August and 16 September 16; Boell op. cit., p. 254.

WL-BL MSS Afr.s.1715 (300), HP Williams, History of 1 KAR, pp. 159-160.

WL-BL, MSS Afr.s.1715 (300); Williams op. cit., p. 158; Boell op. cit., p. 287; WO 95/5329, Norforce WD, 16 and 30 September and 1 October 1916; WO 95/5291, GHQ WD, Telegram OA445, Smuts to CIGS, 24 September 1916.

WO 95/5329, Norforce WD, 16, 17 and 21 September 16; South African National Defence Force (SANDF), Documentation Directorate (DD), Pretoria, German South-West Africa (GSWA), Box 26, Telegram K475, 2 Div to Smuts, 11 September 1916 (confusingly, the documentation for the East African Campaign is filed under the GSWA title); WO 95/5329, Norforce WD, Strength Return 31 December 1916.; Boell op. cit., pp. 254-255, 286-287.

WO 95/5292, GHQ WD, Telegram F5839, Smuts to CIGS, 14 October 1916; WO 95/5329, Norforce WD, 14 October 1916.

WO 95/5292, GHQ WD, Telegram OA569, Smuts to CIGS, 13 October 1916; Stapleton op. cit., pp. $68-69$.

WO 95/5292, GHQ WD, Telegram F5910, Smuts to CIGS, 26 October 1916; Boell op. cit., p. 289; CAB 44/4, pp. 9-12, 17; Maker, Part II op. cit.

WO 95/5292, GHQ WD, Telegram F5917, Smuts to CIGS, 27 October 1916; Boell op. cit., pp. 290291.

Boell op. cit., pp. 256-257; CAB 44/4, pp. 17-20; WL-BL, MSS Afr.s.1715 (300), Williams op. cit. pp. 160-161; Maker, Part II op. cit.

WO 95/5292, GHQ WD, Telegram F5948, Smuts to CIGS, 1 November 1916; WO 95/5329, Norforce WD, 2 and 3-4 November 1916.

CAB 44/4, 27; WO 95/5329, Norforce WD, 30 October and 2, 7 and 8 November 1916; WL-BL, MSS Afr.s.1715 (300), Williams op. cit., pp. 161-162; Boell op. cit., p. 257.

WO 95/5292, GHQ WD, Telegram OA969, General Staff (Genstaff) to CIGS, 7 November 1916; SANDF DD, GSWA, Box 27, Telegram K651, 2 Div to BGGS, 12 October 1916; CAB 44/4, pp. 3942.

WO 95/5292, GHQ WD, Telegram NF 1498, Norforce to Genstaff, 16 November 1916; WO 95/5329, Norforce WD, 11 and 12 November 1916; Boell op. cit., pp. 293-294; CAB 44/4, pp. $28-30$. WO 95/5329, Norforce WD, 8-9 and 17 November 1916; CAB 44/4, pp. 29-30. 
WO 95/5329, Norforce WD, 13, 14 and 18 November 1916; CAB 44/4, pp. 31-32; WL-BL, MSS Afr.s.1715, Williams op. cit., p. 163; Boell op. cit., p. 294; CAB 44/4, p. 48; Northey op. cit., p. 84. WO 95/5292, GHQ WD, 19 November 1916; WO 95/5329, Norforce WD, 17 November 1916; Boell op. cit., pp. 255-256; Stapleton op. cit., pp. 71-74. WO 95/5292, GHQ WD, 29 November 1916.

WO 95/5292, GHQ WD, Telegram OA969, Genstaff, Morogoro to CIGS, 7 November 1916; GHQ WD, 14 November 1916, Telegram OA24, Genstaff, Morogoro to Norforce and Genstaff, Dar-esSalaam, 13 November 1916. WO 95/5292, GHQ WD, Telegram X945, Smuts to CIGS, 25 November 1916. WO 95/5329, Norforce WD, 27-29 November 1916; WL-BL, MSS Afr.s.1715, Williams op. cit., p. 163.

BL, Mss Buxton, Letter John X Merriman to Buxton, 4 December 1916.

SANDF DD, GSWA, Box 29, Telegram P32, 2 Div to BGGS, 18 December 1916; WO 95/5329, Norforce WD, Strength return, 31 December 1916.

WO 95/5329, Norforce WD, 13 December 1916. The mountains reached 9000 feet in altitude and caused considerable sickness and death among his porters.

WO 95/5329, Norforce WD, 1-18 January 1916; CAB 44/7, pp. 22-23.

WO 95/5329, Norforce WD, 19-31 January 1917.

WO 95/5329, Norforce WD, 29 January and 5 February 1917; WO 95/5331, 1/1 ${ }^{\text {st }}$ KAR WD, 29 January 1917.

CAB 44/9, p. 33, Sketch 96.

Boell op. cit., p. 315.

Ibid., p. 325; WL-BL, MSS Afr.c.1715 (300), Williams op. cit., p. 165; Stapleton op. cit., p. 93.

Boell op. cit., p. 325; TNA, WO 95/5320, Norforce WD, 24 February, 10 and 11 March 1917; Hoskins, London Gazette, Supplement No. 30477, 27 December 1917, Despatch from the General Officer Commanding in Chief East Africa relating to operations in East Africa $20^{\text {th }}$ January to $13^{\text {th }}$ May 1917, p. 160 ( henceforth Hoskins Despatch).

Stapleton op. cit., pp. 96-100. Lt Col Tomlinson was removed from command of $1^{\text {st }}$ RNR following this incident and replaced by Maj. Carbutt.

Boell op. cit., p. 326; TNA, WO 95/5329, Norforce WD, 8 March 1917; WO 95/5329, Norforce WD, 22-26 March 1917; Hoskins Despatch, p. 168.

IWM, 49538, KTB, IV, 22 March 1917; Hoskins Despatch, pp. 159-160.

WO 95/5329, Norforce WD, 7 March 1917. 1/4 ${ }^{\text {th }}$ KAR was commanded by Lt Col Shorthose.

WO 95/5329, Norforce WD, 20 March 1917.

WO 95/5329, Norforce WD 12, 17, 23 and 30 March 1917.

WO 33/953/1727, Telegram G738, Hoskins to CIGS, 31 March 1917.

WO 95/5329, Norforce WD, 1 April 1917.

WO 95/5329, Norforce WD, 31 March 1917, "Summary of situation at end of March”; CAB 44/9, pp. $33-34$.

WO 95/5329, Norforce WD, 11 and 27 April 1917; CAB 44/9, pp. 34-35.

WO 95/5329, Norforce WD, 22 and 27 April 1917.

CAB 44/9, pp. 35-36; CAB 45/73, Sketch 98, "The strategic situation first June 1917".

CAB 45/56, Précis Murray Diaries, 4 May 1917.

WO 95/5329, Norforce WD, 2 May 1917; WO 95/5293, GHQ WD, Telegram P19, Edforce to Genstaff, 9 May 1917.

WO 95/5329, Norforce WD, 6 May 1917.

IWM, 49538, KTB, IV, 6 May 1917; WO 95/5329, Norforce WD, 9 May 1917.

WO 95/5329, Norforce WD, 14 and 18 May 1917; CAB 44/9, p. 40.

WO 95/5329, Norforce WD, 25 and 29 May 1917; Pélissier op. cit., pp. 764-765; Newitt, History of Mozambique, London: Hurst \& Company, 1995, pp. 418-419. CAB 44/9, pp. 40-41.

CAB 45/56, Précis Murray Diaries, 28 and 30 May 1917.

CAB 45/56, Précis Murray Diaries, 15 June 1917; WO 95/5329, Norforce WD, 29 May 1917.

WO 95/5329, Norforce WD, 1 June 1917; Telegram Northey to Secretary of State for the Colonies, 4

June 1917; CAB 44/9, p. 42.

CAB 44/9, pp. 41-42.

CAB 44/9, p. 33, Sketch 96.

WO 95/5293, GHQ WD, 26 May 1917, Telegram NF2957, Norforce to Hoskins, 25 May 1917.

WO 95/5329, Norforce WD, 9 June 1917; WO 95/5330, Norforce WD, 'Norforce - Main Column 30 June - 3 November 1917'. 
WO 95/5329, Norforce WD, 3 and 31 July 1917; CAB 44/9, p. 48.

Bundesarchiv-Militärarchiv (BA-MA), Freiburg im Breisgau, Nachlaß Boell, N14/32, 29. Kapitel, pp. 2621-2622; CAB 44/9, pp. 48-49.

BA-MA, Nachlaß Boell, N14/32, 29. Kapitel, pp. 2621-2622.

WO 95/5329, Norforce WD, 2-3, 6 and 7 July 1917; CAB 45/56, Murray Diaries, 1, 7 and 8 July 1917. WO 95/5329, Norforce WD, 8 July 1917.

WO 95/5329, Norforce WD, 10-12 July 1917, Telegram NF4139, Norforce to BGGS; 13 July 1917, Telegram G300 BGGS to Norforce, 13 July 1917.

WO 95/5329, Norforce WD, 15, 24, 26 July and 1 August 1917; Stapleton op. cit., pp. 108-110; Cripwell op. cit., p. 64. Maj. Fair had been appointed acting Lt Col effective 6 August and took command on 11 August 1917.

WO 95/5329, Norforce WD, 1, 5 and 8 August 1917; Cripwell op. cit., pp. 64-65.

WO 95/5329, Norforce WD, 7 August 1917.

WO 95/5329, Norforce WD, 9-10 and 14-16 August 1917; Northey op. cit., p. 85. The meeting was partly made possible by Northey's completion of a motor road from Songea to Iringa, nearly 420 kilometres long.

WO 95/5329, Norforce WD, 21-22, 28 and 30-31 August 1917; Stapleton op. cit., pp. 108-110.

WO 95/5330, Norforce WD, 7 and 12 September 1917.

WO 95/5330, Norforce WD, 30 September 1917.

WO 95/5330, Norforce WD, 1 October 1917.

WO 95/5330, Norforce WD, 5-6 October 1917.

WO 95/5330, Norforce WD, 6-7 and 19 October 1917; Cripwell op. cit., pp. 73-74.

WO 95/5330, Norforce WD, 24 October 1917.

WO 95/5330, Norforce WD, 1 and 6 November 1917.

WO 95/5330, Norforce WD, 12-13 November 1917.

WO 95/5330, Norforce WD, 16, 20 and 24 November 1917; Cripwell op. cit., pp. 75-79. Col Murray was dissatisfied with Lt Col Fair's conduct of the attack on and perceived slowness in pursuing Abt. Aumann in August and September; Fair was relieved of his command and replaced by Lt Col Stennett and later Lt Col Dickinson in 1918.

Stapleton op. cit., pp. 120-121.

WO 95/5330, Norforce WD, 27 November 1917.

WO 95/5330, Norforce WD, 31 December 1917 and 1 January 1918.

WO 95/5330, Norforce WD, 4 January 1918.

WO 95/5330, Norforce WD, 19 January 1918.

"Northey, Maj. Gen. Sir Edward" op. cit.

WO 95/5330, Norforce WD, 4 and 7 January 1918; IWM, 49538, KTB, IV, 10 January 1918; Boell papers, N14/36, 2. Kapitel, p. 49.

WO 95/5330, Norforce WD, 14 and 18 January 1918; WO 95/5295, GHQ WD, 4 January 1918; London Gazette, Supplement No. 31069, 16 December 1918, Despatch from the Lieutenant-General Commanding-in-Chief, East African Force, 30 September 1918, p. 121 (henceforth Van Deventer Despatch).

WO 95/5330, Norforce WD, 19 January 1918.

BA-MA, Nachlaß Boell, N14/36, 2. Kapitel, pp. 32-33, 49.

WO 95/5330, Norforce WD, 20 January 1917; BA-MA, Nachlaß Boell, N14/36, 2. Kapitel, pp. 66-67; Boell op. cit., p. 404.

WO 95/5330, Norforce WD, 30 January 1918; Stapleton op. cit., pp. 102, 121-122; Northey op. cit., p. 85.

WO/95/5295, GHQ WD, 12 February 1918.

WO 95/5330, Norforce WD, 4 February 1918.

WO 95/5330, Norforce WD, 11 February 1918.

WO 95/5330, Norforce WD, 12 and 14 February 1918.

WO 95/5330, Norforce WD, 22-24 February 1918.

Van Deventer Despatch, II, p. 122; Boell op. cit., p. 404; WO 95/5330, Norforce WD, 22 February 1918.

WO 95/5330, Norforce WD, 23-24 February 1918.

CO 691/15, Norforce WD, 12 March 1918.

CO 691/15, Norforce WD, 28 March and 1 April 1918.

CO 691/15, Norforce WD, 13-16 April 1918.

CO 691/15, Norforce WD, 21 April 1918. 
15

156

157

158

159

160

CO 691/15, Norforce WD, 5 May 1918; Boell op. cit., p. 404.

CO 691/15, Norforce WD, 22-23 May 1918.

CO 691/15, Norforce WD, 27-28 May 1918

CO 691/15, Norforce WD, 7 June 1918.

CO 691/15, Norforce WD, 17, 25 and 28 June 1918.

"Court circular". Times [London]. 26 September 1918. 9. The Times Digital Archive. $\langle$ http://find.galegroup.com.ezproxy.londonlibrary.co.uk/ttda/infomark.do?\&source=gale\&prodId=TTD A\&userGroupName $=$ lonlib\&tabID $=$ T003\&docPage $=$ article \&searchType $=\&$ docId $=C S 151194426 \&$ typ e=multipage\&contentSet=LTO\&version=1.0 $>$; "Court circular". Times [London]. 25 November 1918. $11 . \quad$ The Times Digital Archive. $<$ http://find.galegroup.com.ezproxy.londonlibrary.co.uk/ttda/infomark.do?\&source=gale\&prodId=TTD A\&userGroupName $=$ lonlib\&tabID $=$ T003\&docPage $=$ article \&searchType $=\&$ docId $=C S 184879993 \&$ typ e=multipage \&contentSet=LTO\&version $=1.0>$. 